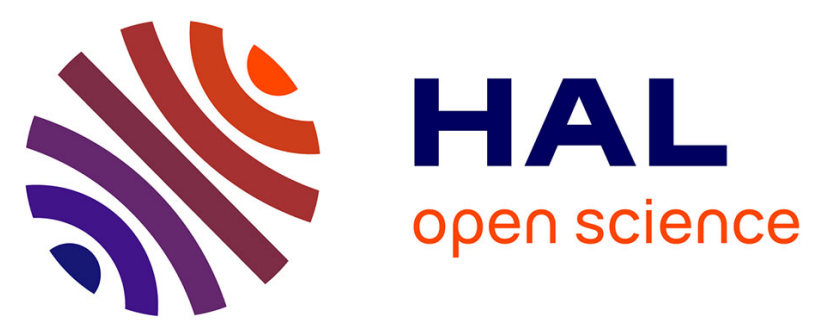

\title{
Neanderthal faunal exploitation and settlement dynamics at the Abri du Maras, level 5 (south-eastern France)
}

Juan Marin, Camille Daujeard, Palmira Saladié, Antonio Rodríguez-Hidalgo, Delphine Vettese, Florent Rivals, Nicolas Boulbes, Evelyne Crégut-Bonnoure, Nicolas Lateur, Rosalia Gallotti, et al.

\section{To cite this version:}

Juan Marin, Camille Daujeard, Palmira Saladié, Antonio Rodríguez-Hidalgo, Delphine Vettese, et al.. Neanderthal faunal exploitation and settlement dynamics at the Abri du Maras, level 5 (south-eastern France). Quaternary Science Reviews, 2020, 243, pp.106472. 10.1016/j.quascirev.2020.106472 . hal02957845

\section{HAL Id: hal-02957845 \\ https://hal.science/hal-02957845}

Submitted on 13 Nov 2020

HAL is a multi-disciplinary open access archive for the deposit and dissemination of scientific research documents, whether they are published or not. The documents may come from teaching and research institutions in France or abroad, or from public or private research centers.
L'archive ouverte pluridisciplinaire HAL, est destinée au dépôt et à la diffusion de documents scientifiques de niveau recherche, publiés ou non, émanant des établissements d'enseignement et de recherche français ou étrangers, des laboratoires publics ou privés. 


\section{Neanderthal faunal exploitation and settlement dynamics at the Abri du Maras, Level 5 (South-eastern France)}

Juan Marín a , Camille Daujeard a , Palmira Saladié ${ }^{\text {b,c,d }}$, Antonio Rodríguez-Hidalgo e,f,b, Delphine Vettese $^{\mathrm{a}, \mathrm{g}}$, Florent Rivals ${ }^{\mathrm{b}, \mathrm{c}, \mathrm{h}}$, Nicolas Boulbes ${ }^{\mathrm{a}, \mathrm{i}}$, Evelyne Crégut-Bonnoure ${ }^{\mathrm{j}, \mathrm{k}}$, Nicolas Lateur ${ }^{1}$, ${\text { Rosalia Gallotti }{ }^{\mathrm{m}, \mathrm{n}} \text {, Louis Arbez }}^{\mathrm{o}, \mathrm{p}}$, Simon Puaud $^{\mathrm{a}}$, Marie-Hélène Moncel ${ }^{\mathrm{a}}$

a Histoire Naturelle de l'Homme Préhistorique (HNHP), Muséum national d'histoire naturelle, CNRS, UPVD, 1 Rue René Panhard, 75013 Paris, France.

${ }^{\mathrm{b}}$ Institut Català de Paleoecologia Humana i Evolució Social (IPHES), Zona Educacional 4, Campus Sescelades URV (Edifici W3), 43007 Tarragona, Spain.

${ }^{\mathrm{c}}$ Universitat Rovira i Virgili, Departament d'Història i Història de l'Art, Avinguda de Catalunya 35, 43002 Tarragona, Spain.

${ }^{\mathrm{d}}$ Unit Associated with CSIC, Departamento de Paleobiologia, Museo Nacional de Ciencias Naturales, Madrid, Spain.

e Universidad Complutense de Madrid, Departamento de Prehistoria, Historia Antigua y Arqueología, Fac. de Geografía e Historia, Edificio B, C/ Profesor Aranguren s/n, 28040, Madrid

${ }_{\mathrm{f}}^{\mathrm{f}}$ Instituto de Evolución en África (IDEA), Calle Covarrubias 36, 28010, Madrid, Spain.

g Università degli Studi di Ferrara, Dipartimento degli Studi Umanistici, Sezione di Scienze Preistoriche e Antropologiche, Corso Ercole I d'Este 32, 44121 Ferrara, Italy.

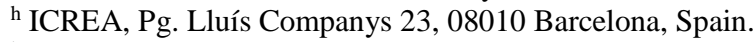

${ }^{\mathrm{i}}$ UMR 7194 Histoire Naturelle de l'Homme Préhistorique, Université de Perpignan Via Domitia-Museum National d'Histoire Naturelle-CNRS, EPCC-CERP, Tautavel, France.

j UMR 5608 TRACES - Univ. de Toulouse-Jean Jaurès, 5 Allée Antonio-Machado, F-31058 Toulouse cedex 9

${ }^{\mathrm{k}}$ Museum Requien, 67 rue Joseph Vernet, 84000, Avignon, France.

${ }^{1}$ Aix Marseille Univ, CNRS, Minist Culture, LAMPEA, Aix-en-Provence, France

${ }^{\mathrm{m}}$ Universite Paul Valery Montpellier 3, CNRS, UMR 5140 Archeologie des societes mediterraneennes, Campus Saint Charles, 34199, Montpellier, France

${ }^{\mathrm{n}}$ Universite Bordeaux 1 UMR 5199 PACEA-PPP, B^atiment B18 allee Geoffroy Saint-Hilaire CS 50023, F - 33615, Pessac Cedex, France

${ }^{\circ}$ EPHE, PSL University, 6 Boulevard Gabriel, 21000 Dijon, France

p Biogéosciences, UMR 6282, CNRS, EPHE, Université Bourgogne Franche-Comté, 6 Boulevard Gabriel, 21000 Dijon, France

Corresponding autor:

Juan Marín, Histoire Naturelle de l'Homme Préhistorique (HNHP), Muséum national d'histoire naturelle, CNRS, UPVD, 1 Rue René Panhard, 75013 Paris, France.

Juan.marin.hernando@gmail.com

\section{Abstract}

Over the past two decades, taphonomic and zooarchaeological studies have focused on Neanderthal settlement patterns and subsistence strategies. The south-eastern margins of the Massif Central constitute one of the regions with the most abundant archaeological evidence of Neanderthal occupations in France. The faunal record of level 5 of Abri du Maras is a unique source of information for analysing Neanderthal behaviour at the end of the MIS5. The assemblage is divided into three levels 5.1, 5.2 and 5.3, which correspond to the three main phases of human occupation of the shelter in level 5. Through the taphonomic and zooarchaeological analysis of the faunal remains, we define the characteristics of human occupation developed in the rock shelter. In this paper, we show that Neanderthal groups used the Abri du Maras as a residential campsite for long-term occupation events during a whole season, mainly summer. The intensive exploitation of the faunal 
resources is typical of a residential campsite, and the selective seasonal hunting strategy of medium and large ungulates, centred on prime adults, indicates different Neanderthal subsistence patterns to the upper levels of the sequence. Here, our results document the chronological changes in occupation patterns in one of the reference sites in south-eastern France and address questions related to cultural choices and environmental constraints.

Keywords: Zooarchaeology; Taphonomy; Microwear; Neanderthals; Campsite; Hunting strategies; Subsistence

\section{Introduction}

Zooarchaeological studies of Middle Palaeolithic assemblages have proven to be a fundamental tool for understanding Neanderthal behaviour (Costamagno et al., 2006; Gaudzinski and Roebroeks, 2000; Niven, 2013; Niven et al., 2012; Patou-Mathis, 2000). The current state of knowledge indicates that Neanderthals were effectively hunted a wide faunal spectrum, from the megafauna to small preys (Adler and Bar-Oz, 2009; Costamagno et al., 2006; Daujeard and Moncel, 2010; Farizy et al., 1994; Fernández-Peris et al., 2008; Gabucio et al., 2014a; Gaudzinski and Roebroeks, 2000; Hardy and Moncel, 2011; Jaubert and Brugal, 1990; Patou-Mathis, 1994, 2012; Rufà et al., 2014, 2016; Smith, 2015; Stiner, 1991; Stiner et al., 2009; Stiner, 2013; Stiner and Kuhn, 2006). However, the large number of faunal remains found in Middle Palaeolithic sites indicates that the consumption of large- and medium-sized ungulates was essential for these groups (Adler et al., 2006; Brugal, 2001; Burke, 2000; Castel et al., 2017; Costamagno et al., 2006; Farizy et al., 1994; Gaudzinski, 2006; Gaudzinski and Roebroeks, 2000; Gaudzinski-Windheuser et al., 2018; Jaubert and Brugal, 1990; Stiner, 1994; Yravedra and Cobo-Sánchez, 2015). It is even more significant if we consider the importance of meat from ungulates in the Neanderthal diets suggested by numerous isotopic analysis in bone collagen over their remains (Bocherens, 2011; Bocherens et al., 2016; Jaouen et al., 2019; Naito et al., 2016; Richards, 2009; Richards and Trinkaus, 2009; Wißing et al., 2016).

Zooarchaeological studies, together with lithic technology studies (Delagnes et al., 2007; Delagnes and Meignen, 2006; Dibble, 1995; Eixea, 2018; Kuhn, 1992; Vaquero, 2008; Villa and Lenoir, 2009) have served as the basis for our knowledge of Middle Palaeolithic subsistence and adaptive strategies (Carrión and Walker, 2019; Marean, 2005; Speth, 2012; Stiner, 2013, 1994). Such researchs explores mobility and settlement dynamics, leading to the identification of territorial organization for Middle Palaeolithic groups (Audouze, 2010; Boyle, 2000; Burke, 2000; Delagnes and Rendu, 2011; Farizy, 1994; Patou-Mathis, 2000; Turq et al., 2017). 
The Middle Palaeolithic record from the south-eastern Rhône valley region has been widely studied, and Abri du Maras is one of the main reference sites (Daujeard et al., 2019; Daujeard and Moncel, 2010; Moncel and Daujeard, 2012; Moncel, 2010; Moncel et al., 2019, 2004). Daujeard and Moncel (2010) identified three main types of sites in the area: 1) Type I: Long-term residential camps characterized by recurrent human accumulation (high rate of anthropogenic modifications), seasonal selective hunting with a specialized hunting spectrum, transport of whole carcasses or best pieces, presence of bone retouchers, complete or mostly complete lithic sequences on local stones, a low percentage of tools; 2) Type II: Short-term regular camps, with recurrent human accumulation interspersed with carnivore visits, seasonal selective hunting with a varied herbivore spectrum, with scavenging events, particularly of very big animals, some retouchers, mostly complete lithic sequence on flint, exogenous flint, a moderate number of tools; 3) Type III: Brief stopping-places: natural or carnivore accumulations with some human occupations, very scarce or absent burnt bones, scarce or absent retouchers, mostly complete lithic sequences, high proportions of tools and low density of lithic remains. This regional analysis enabled us to interpret the regional land use pattern of Neanderthal groups as a farsighted circulating model, with recurrent base camps and satellite hunting camps. In this classification, Abri du Maras was defined as an archaeological type I site (Daujeard and Moncel, 2010). In more recent work, the occupation of level 4.1 was described as a campsite for short but repeated occupations, in which Neanderthal groups developed hunting centred on the mass killing of reindeer herds, probably when they crossed the Ardèche River during the autumn migration (Daujeard et al., 2019).

The Abri du Maras rock shelter is one of the reference sites for the study of Neanderthal behaviour. The site was studied from a multidisciplinary point of view for over ten years (Daujeard et al., 2019; Hardy et al., 2020, 2013; Moncel et al., 2014, 2010; Puaud et al., 2015; Richard et al., 2015; Vettese et al., 2017). In this paper, we present the zooarchaeological analysis of the faunal assemblage from level 5 of Abri du Maras, recovered during fieldwork carried out from 2006-2018. The aim is to identify the use of the site during the formation of this level and the occupation pattern through a complete zooarchaeological and taphonomical study of the faunal assemblage. We focus on taxonomical representation, hunting and prey selection, and the transport of carcass elements to the site in order to compare level 5 with the other levels of the Middle Palaeolithic sequence of Abri du Maras and with other sites from the regional context of the Rhône valley. 


\section{The Abri du Maras Rock Shelter}

\subsection{General description}

The Abri du Maras is located in a small dry valley, less than $1 \mathrm{~km}$ long, perpendicular to the Ardèche River valley, a tributary of the Rhone River, near the locality of Saint-Martin d'Ardèche. It is situated $170 \mathrm{~m}$ above sea level and $70 \mathrm{~m}$ above the Ardèche River. The rock shelter was excavated by R. Gilles and J. Combier in the 1950s and 1960s, who described sequence composed of eight archaeological levels (Combier, 1967). In 2006, a survey at the front of the site identified two levels at the base of the sequence (named levels 4 and 5) and provided the first overview of the site (Moncel et al., 2010) (Figure 1). This survey was followed by renewed excavations.

The geological study shows that the cave roof collapsed over time and that the most recent occupations took place under a small shelter (Debard, 1988). The oldest level identified during recent excavations was named level 5 (levels 8-6 of the previous excavations) and consists of a thick organic brown level with a sandy-silty matrix, covering the limestone substratum. It is truncated in front of the site and covered by a sterile level of rubble with a red clay silt matrix. The overlying deposit is level 4 (levels 5-4 of the previous excavations), made up of homogeneous aeolian silt (loess) with some small blocks of limestone. Two phases of occupation have been identified and dated to MIS 3 (Richard et al., 2015). This level is overline by levels 3, 2 and 1, made up of rubble with a silty matrix and limestone slabs, similar to those described during the previous excavations. These levels contain the most recent occupations (Moncel et al., 2010). The latter also significantly reduced the ceiling height of the shelter, leading to a shift in the surface of the human occupations, to the limit of the shelter roof. U-The dating of four bone samples from level 5 would place this level between 70 and $90 \mathrm{ka}(72 \pm 3 \mathrm{ka}, 87 \pm 5 \mathrm{ka}, 89 \pm 4 \mathrm{ka}, 91 \pm 4 \mathrm{ka})$, at the end of MIS 5 or the beginning of MIS 4 (Moncel and Michel, 2000). Level 4.1 in the Abri du Maras is dated to between $40 \pm 3 \mathrm{ka}$ and $46 \pm 3 \mathrm{ka}$ (MIS 3), while samples from level 4.2 provided ages ranging from $42 \pm 3 \mathrm{ka}$ to $55 \pm 2 \mathrm{ka}$ (MIS 3). These new ages obtained on level 4.1 and 4.2 indicate that the site was occupied during MIS 3, and thus extend the known chronology of Abri du Maras (end of MIS 4- the beginning of MIS 5, Moncel and Michel, 2000). One sample (AM F6-47), positioned at the top of level 5 upper in the western part of the site, gave an age of $90 \pm 9 \mathrm{ka}$ (MIS 5c-b), in agreement with the previous dating study (Richard et al., 2015).

The study of large ungulates serves as an approach to paleoenvironmental evidence. Here, it indicates the development of cold weather over time and a decrease in forested areas in favour of more open steppe landscapes (reindeer succeeding deer), which is in line with sedimentological 
results (Debard, 1988; Moncel et al., 2018, 1994). The paleontological analysis in level 4.1 and 4.2 revealed the presence of Rangifer tarandus, Equus ferus cf. germanicus, Cervus elaphus, Bison priscus, Capra ibex and Megaloceros giganteus (Boulbes and van Asperen, 2019; Daujeard, 2008; Moncel et al., 1994). The zooarchaeological analysis of levels 4.1 and 4.2 indicates that these levels result from Neanderthal activity, characterized by a primary access to animal carcasses, systematic transport of skeletal elements to the rock shelter and a complete exploitation of animal resources (Daujeard, 2008; Daujeard et al., 2019; Moncel et al., 2018).

Lithic remains were abundant throughout the sequence. Level 4.1 and level 4.2 contain predominant Levallois production with the importation of large products and complementary in situ knapping of flakes from small nodule cores (Moncel, 1994). Technological strategies point to the fragmentation of processes in a local and semi-local perimeter around the rock shelter (Moncel et al., 2018). Large flakes, blades, and points were produced elsewhere and brought to the occupations with flint and other raw materials, nodules and fragments of slabs for in situ knapping. Evidence of fire can be seen in the levels 4 and 5. It consist, besides the charcoal, in the presence of fine lenses of ashes whose edges are well preserved, which contain scattered ashes, bones and some burnt flints. Based on their vertical distribution, these lenses mark major episodes of occupation (Moncel et al., 2018). 


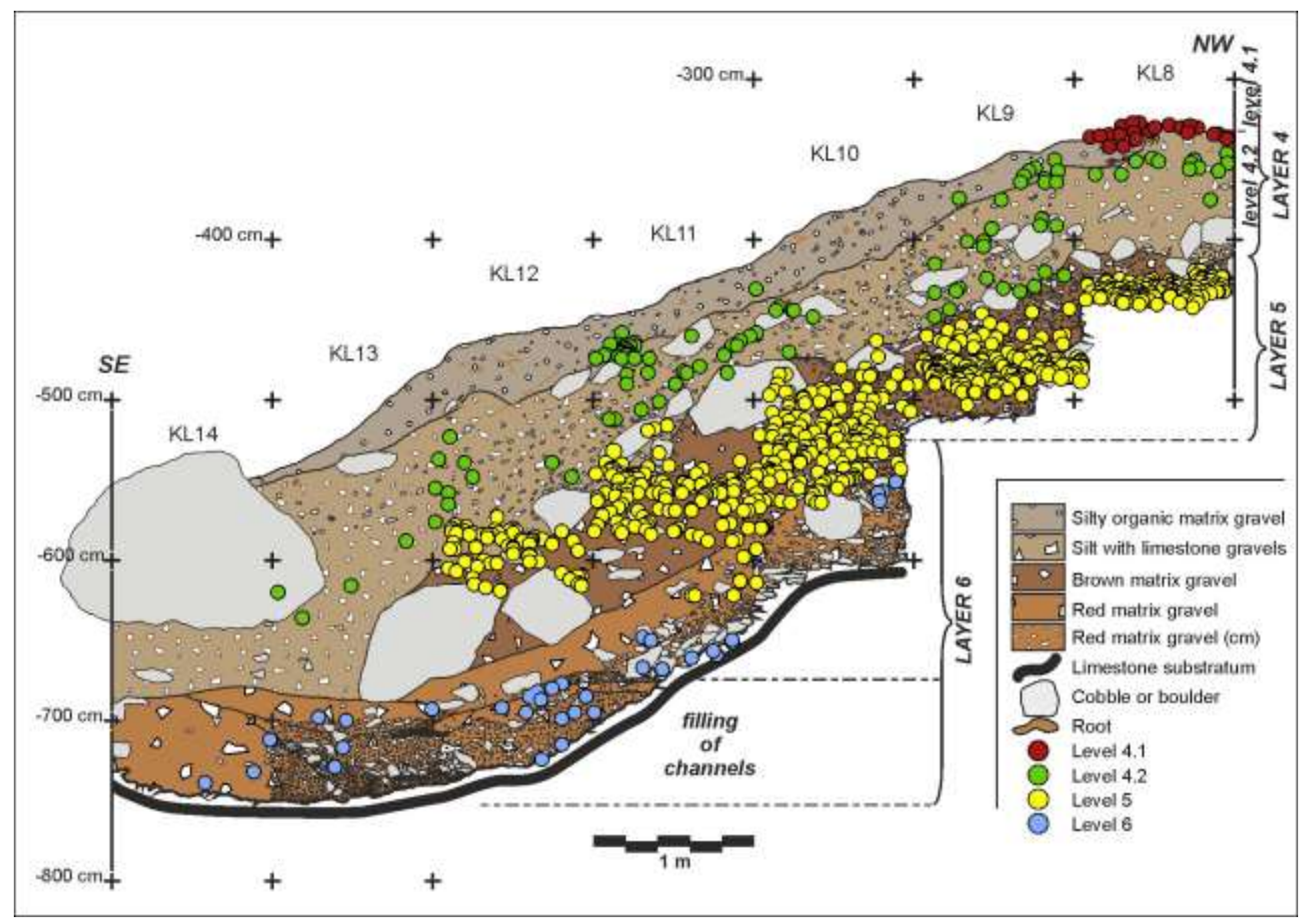

Figure 1 Vertical distribution of the archaeological material at Abri du Maras. Abri du Maras materials: green=level 4.1; red=level 4.2; yellow=level 5; blue=level 6 .

\subsection{Level 5}

The upper part of level 5 is covered by a dense bed of large- and middle-sized blocks (between 50 $\mathrm{cm}$ and $4.5 \mathrm{~m}$ thick), resulting from the major collapse of the shelter. This bed delimits the level 4 from the level 5. The thickest zone of this phase of accumulation is observed in the central and eastern parts of the site and is estimated at a thickness of $160 \mathrm{~cm}$ at the most. Level 5 lies on the limestone bedrock, excavated in front of the shelter, or partially covers the underlying level 6, a red and karstic deposit with some evidence of occupation. The bedrock cross-section resembles a series of steps and the infilling lies on the series of steps. Level 5 is considered as a distinct deposit in the sequence due to the similarity of the type and structure of the sediment, which consist of series of several layers of brown clay including small or large blocks resulting from the collapse of the shelter over time (Figure 1).

Three phases of occupations have been distinguished by means of the systematic plotting of the material from the sequence along $50 \mathrm{~cm}$ sections and by projections of spatial distributions of the material (Figure 2). Phase 5.1 corresponds to the upper part of the level, with a dense concentration of archaeological material located just under the blocks. It has been excavated over $25 \mathrm{~m}^{2}$. It can be 
distinguished from phase $5.2\left(15 \mathrm{~m}^{2}\right)$ by a lower density of archaeological material. The main discontinuity is observed in the lower part of the level where a sterile bed of small- and middlesized blocks results from a minor collapse of the shelter. This bed delimits the phase of occupation phase $5.3\left(15 \mathrm{~m}^{2}\right)$ from the overlying phase 5.2. A higher diversity of core technologies, including Levallois technology, differentiates technological behaviours in level 5 from level 4 . The ratio of flake tools (and diversity) is higher (around 10\% as opposed to less than $5 \%$ for level 4). Flint still dominates the corpus, associated with other stones, debitage products, some cores and entire pebbles. The flint types indicate a perimeter of procurement to the south (Orgnac plateau; $20 \mathrm{~km}$ aprox.) and the north of the site.

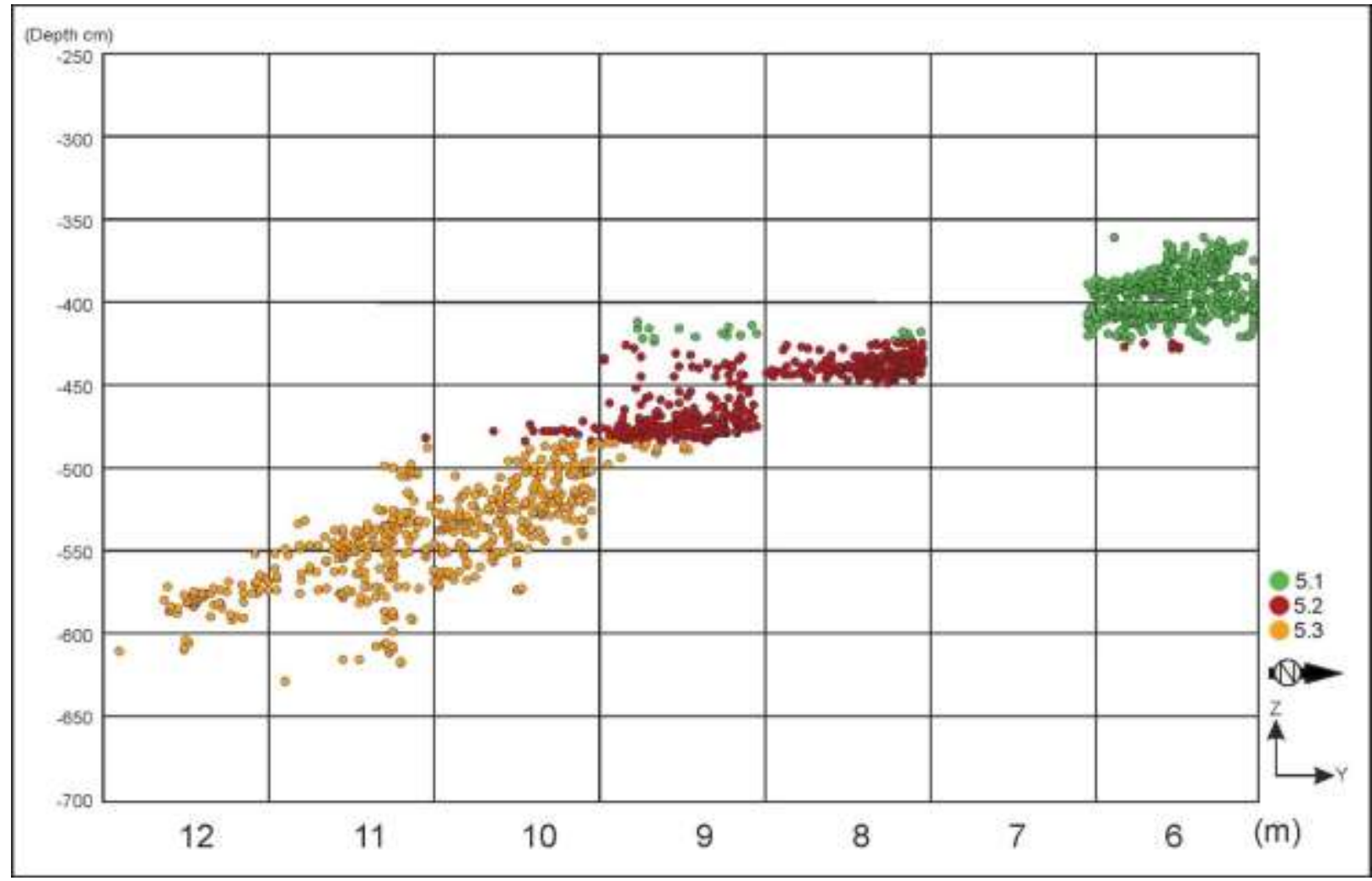

Figure 2 Vertical distribution of archaeological material of level 5 in the L line. Level 5.1=green; Level 5.2=red; Level 5.3= yellow.

\section{Materials and Methods}

A total of 5,383 faunal remains were analysed for this work: 2,511 faunal remains from level 5.1; 1,415 faunal remains from level 5.2; 1,458 faunal remains from level 5.3 were studied. Systematic dry sieving was undertaken during the excavations.

Taxon, age at death, weight category, element, side (anterior, posterior, medial, lateral, superior and inferior) and the portion (epiphysis, metaphysis and diaphysis) and position (left/right) were described when possible. For taxonomic identification were used the reference collection of the Sale d'anatomie Comparée of the Muséum national d'historie naturel (MNHN) and the reference 
collection of the institut de paleontologie humaine (IPH) and for anatomical nomenclature was used the reference of Barone (Barone, 1976). Carcasses were divided into anatomical parts to estimate anatomical representation: axial cranial (horns/antlers, skull, mandible, hyoid and isolated teeth), axial postcranial (vertebrae, ribs, scapula and coxal) and appendicular (extremities). The scapula was classified with the axial skeleton because it responds to taphonomic processes in a similar way to the rest of the axial skeleton elements (Yravedra and Domínguez-Rodrigo, 2009). Long bones were divided into upper appendicular bones (humerus and femur), intermediate (radius/ulna and tibia) and inferior (metapodials) (Domínguez-Rodrigo, 1997). Three weight categories were used for the analysis of level 5: large animals weighing between 300 and 1,000 $\mathrm{kg}$ (horse, bison); medium-sized animals weighing between 50 and $300 \mathrm{~kg}$ (reindeer, red deer, wild boar, ibex); smallsized animals weighing less than $50 \mathrm{~kg}$ (roe deer, fallow deer, wolf).

Four measures of abundance were used in this work: Number of Specimens (NSP); Number of Identified Specimens (NISP); Minimum Number of Elements (MNE); Minimum Number of Animal Units standardized (\%MAU); and Minimum Number of Individuals (MNI) (Binford, 1984; Grayson, 1984; Lyman, 1994). To calculate the NISP were considered fragments whose precise location in the skeletal element could be determined, quantified and assigned to species or size class. To calculate the MNE, the superposition of anatomical markers, the age or side were considered. For long bones, we followed the recommendation of Saladié et al. (2011), dividing bones using a numerical system of five fixed portions: portions 1 and 5 proximal and distal epiphysis; portions 2 most proximal part of diaphysis; portion 3 medial region of diaphysis; portion 4 most distal part of diaphysis. The Simpson diversity index (D) were used to establish the degree of taxonomic diversity (Faith and $\mathrm{Du}, 2018$ ).

Spearman's rank-order was used to test the correlation between the \%MAU and the data provided by Lam et al. (1999) for bone mineral density, taking into account the MNE of each element. The significance of the Spearman correlation coefficient used in this work is $95 \%(0.05)$.

Transport strategy analysis was carried out following the method proposed by Faith and Gordon (2007), through the statistical correlation of Spearman's rho between the standardized food utility index (SFUI) and the \%MAU and by applying the Shannon uniformity index (E) to the anatomical profile. The following high-survival elements were considered: skull, mandible, humerus, radius/ulna, metacarpal, femur, tibia, and metatarsal (Marean and Cleghorn, 2003). In addition, the $\% \mathrm{MAU}$ of the high-survival elements was correlated with the unsaturated marrow index (UMI) proposed by Morin (2007). 
The age at death of the individual and the seasonality of the formation of assemblages were calculated based on the time of eruption and replacement of teeth and the degree of wear of the occlusal surfaces (Azorit, 2011; Bignon, 2006; Bouchud, 1966; Brown and Chapman, 1991; Fernandez and Legendre, 2003; Klein and Cruz-Uribe, 1983; Mariezkurrena, 1983; C. Miller, 1974; F. L. Miller, 1974; Steele and Weaver, 2002). For the calculation of age according to epiphyseal fusion of the bones we follow the criteria proposed by Murray (1993) for reindeer. The birth period for reindeer and horses was between the end of spring and the beginning of summer (horse: Levine, 1982; Burke, 2002) (reindeer: Daujeard et al., 2019). Given that the period of birth and the replacement of deciduous teeth occur at predictable times of the year, it is possible to calculate the annual cycle and estimate the season of death (Stiner, 1990). Once the age at death was identified, individuals were grouped into juveniles, prime adults and old individuals (Stiner, 1990), and plotted within triangular graph following the separation of mortality profiles proposed by Stiner (1990) and Discamps and Costamagno (2015) for reindeer and horses.

Moreover, tooth microwear was used to establish the relative duration and to confirm the seasonality of the formation of the assemblages. Tooth microwear patterns (microscopic features present on the surface of the enamel) were examined for the most represented species in the assemblage, Rangifer tarandus and Equus ferus. The analysis was performed following the protocol established by Solounias and Semprebon (2002). High-resolution dental casts were observed under transmitted light with a Zeiss Stemi 2000C stereomicroscope at 35x magnification. The microwear features (i.e., scratches and pits) were quantified on the paracone of the upper molars or the protoconid of the lower molars. Two measurements of the variability of scratch density, i.e., the standard deviation (SD) and coefficient of variation (CV) were used to estimate the duration of the accumulation of faunal associations (Rivals et al., 2015). The integration of these two measures of variability allows for the classification of each case in one of the following three categories: [A] seasonal or shorter events, [B] events longer than a season (i.e., two or more contiguous seasons), [C] distinct events that occurred in different and non-contiguous seasons. Additionally, the difference in variability among samples was tested using the Bartlett test of homogeneity of variances.

The method devised by Villa and Mahieu (1991) was followed to establish the degree of fragmentation and the agents responsible for bone breakage. For this, we considered diaphysis length and circumference, description of the delineation (longitudinal, transverse and curved / Vshape), angle (straight, oblique or mixed) and the surface (smooth or jagged) of fracture planes. 
The taphonomic analysis was completed by the observation of bone surface modifications using the binocular stereomicroscope (OPTHEC 120-Hz model). We have assessed the visibility of the cortical bone surfaces based on how much surface could be studied: $0=$ none; $1=$ one third; $2=$ two thirds; $3=$ the whole surface. For the identification of weathering stage we followed to Behrensmeyer (1978). The study focused on modifications produced during the nutritional phase (Capaldo, 1998). Damage produced by hominins and carnivores was described according to the anatomical region and the portion on which they were found. The identified anthropogenic modifications include cut marks (Binford, 1981; Domínguez-Rodrigo et al., 2009; Potts and Shipman, 1981; Shipman, 1981; Shipman and Rose, 1983) and percussion marks (Blumenschine and Selvaggio, 1988; Capaldo and Blumenschine, 1994; Vettese et al., 2020). The type, delineation, situation, and position of the cut marks per element allowed us to infer butchery activities. For this, we used ethnoarchaeological sources (Abe, 2005; Binford, 1978), experimental data (Frison, 1974; Nilssen, 2000) and our experiments on multiple animals. For the study of cremations, colour changes of the bones were taken into account, following Cáceres' proposal (2002). The six colouration stages used here are: 0) unburned; 1) small brown or black areas; 2) brown bones; 3) black bones (charred); 4) grey bones(calcined); 5) white bones (calcined). Finally, carnivore modifications were identified through the presence of tooth marks, mainly pits and scores (Blumenschine, 1995; Bunn, 1981; Domínguez-Rodrigo and Barba, 2006; Fisher, 1995; Shipman, 1981), along with furrowing and chipping of the back edges.

For the study of bone retouchers, we used the criteria detailed by Mallye et al. (2012) and Daujeard et al. (2014). We noted the taxonomic and anatomical information. Marks were classified depending on their type, location and orientation.

\section{Results}

\subsection{Taxonomic distribution}

A total of 11 species were identified (Table 1). The identification rate was high in all the levels, $26.8 \%$ in level 5.1, $19.7 \%$ in level 5.2 and $31.5 \%$ in level 5.3. The three assemblages were dominated by Rangifer tarandus $(5.1=74 \% ; 5.2=61.6 \% ; 5.3=64.8 \%)$, followed in importance by Equus ferus $(5.1=10.7 \% ; 5.2=18.6 \% ; 5.3=25.0 \%)$, Cervus elaphus $(5.1=11.3 \% ; 5.2=11.8 \%$; $5.3=4.3 \%)$, and Bison priscus $(5.1=2.8 \% ; 5.2=6.5 \% ; 5.3=5.9 \%)$. Other taxa represented less than $1 \%$ of the total. Sus scrofa remains were identified in levels 5.1 and 5.2, Capreolus capreolus, Capra ibex, Equus hydruntinus and Oryctolagus cuniculus in level 5.1, and Dama dama in level 5.2 (Table 1). A Canis lupus metacarpal in level 5.2 is the only carnivore bone. The levels show a 
uniform distribution of species, as indicated by the Simpson index (Simpson: 5.1=0.574; 5.2=0.433; $5.3=0.4875$ ). Many indeterminate remains could be assigned to a weight category. Medium-sized animals dominated the three assemblages $(40.2 \% ; 41.4 \% ; 35.5 \%)$, followed by large-sized remains $(11.6 \% ; 12.3 \% ; 18.4 \%)$. This distribution is in keeping with the representation of reindeer, red deer and horses in the assemblages.

\begin{tabular}{|l|l|l|l|l|l|l|l|l|l|}
\hline \multirow{2}{*}{ Taxon } & 5.1 & \multicolumn{3}{|l|}{5.2} & \multicolumn{3}{l|}{5.3} \\
\cline { 2 - 11 } & NISP & \%NISP & MNE & NISP & \%NISP & MNE & NISP & $\%$ NISP & MNE \\
\hline Rangifer tarandus & 498 & 74.0 & 116 & 172 & 61.6 & 43 & 298 & 64.8 & 84 \\
\hline Cervus elaphus & 75 & 11.3 & 27 & 33 & 11.8 & 15 & 20 & 4.3 & 10 \\
\hline Dama dama & & & & 1 & 0.4 & 1 & & & \\
\hline Equus ferus & 72 & 10.7 & 25 & 52 & 18.6 & 19 & 115 & 25.0 & 42 \\
\hline Equus hydruntinus & 1 & 0.1 & 1 & & & & & & \\
\hline Bison priscus & 19 & 2.8 & 11 & 18 & 6.5 & 9 & 25 & 5.9 & 13 \\
\hline Capreolus capreolus & 4 & 0.6 & 4 & & & & & & \\
\hline Capra ibex & 2 & 0.3 & 1 & & & & & & \\
\hline Sus scrofa & 1 & 0.1 & 1 & 2 & 0.7 & 2 & & & \\
\hline Canis lupus & & & & 1 & 0.4 & 1 & & & \\
\hline Oryctolagus cuniculus & 2 & 0.3 & 2 & & & & & & \\
\hline Total & $\mathbf{6 7 6}$ & & $\mathbf{1 8 7}$ & $\mathbf{2 7 9}$ & & $\mathbf{9 0}$ & $\mathbf{4 5 8}$ & & $\mathbf{1 4 9}$ \\
\hline Large size & 213 & 11.6 & & 140 & 12.3 & & 184 & 18.4 & \\
\hline Medium size & 738 & 40.2 & & 470 & 41.4 & & 355 & 35.5 & \\
\hline Small size & 28 & 1.5 & & 10 & 0.9 & & 12 & 1.2 & \\
\hline Indeterminate & 858 & 46.7 & & 516 & 45.4 & & 449 & 44.9 & \\
\hline Total & 2,511 & & & 1,415 & & & 1,458 & & \\
\hline
\end{tabular}

Table 1 NISP, NSP and MNE of taxa and weight size categories in levels 5.1, 5.2 and 5.3 of Abri du Maras.

\subsection{Anatomical distribution, bone assemblage integrity and bone transport strategy}

The distribution of NISP and MNE by taxa and elements is presented in tables S1, S2 and S3 of Supplementary materials. The anatomical distribution of reindeer in levels 5.1 and 5.2 shows a predominance of long limb bones, especially by hindlimbs (tibiae, femurs and metatarsals), with low percentages of cranial elements and even lower proportions of postcranial axial elements and compact bones (Figure 3). Conversely, reindeer cranial elements are well represented in level 5.3.

The anatomical distribution of red deer was dominated by long limb bones in levels 5.1 and 5.2. In level 5.1, percentages of tibiae, radii and humerus reached over 50\% and in level 5.2 humerus, tibiae, metacarpals and femurs reached over 50\%. In level 5.3, the most represented elements were skull fragments, scapulae and humerus. The rest of the long limb bones represented 50 of the total remains. The anatomical distribution of the horse is dominated by cranial elements in all the three levels. In level 5.1, mandibular remains are prevalent and in levels 5.2 and 5.3, skull remains are 
predominant. The representation of post-cranial axial elements is low in all three levels. In level 5.1, rib fragments were identified and level 5.2 comprised coxal elements. The post-cranial axial skeleton was best represented in level 5.3, with fragments of hyoid, rib, vertebrae, scapula and coxal bones. Long limb bones were most represented in level 5.2, with abundant femurs and tibiae and proportions of humerus and radii exceeding $60 \%$ and 50\% respectively. In levels 5.1 and 5.3, none of the long limb bone \%MAU proportions exceeded 30\%. Bison remains were dominated by long limb bones, although cranial remains, especially mandible, and coxal remains were presented in the three levels. In level 5.1, radius and tibia percentages exceed 50\%. In level 5.2 the humerus, radius and tibia are the best represented bones, and in level 5.3 the radius is predominant, followed by the humerus, cranium and mandible.

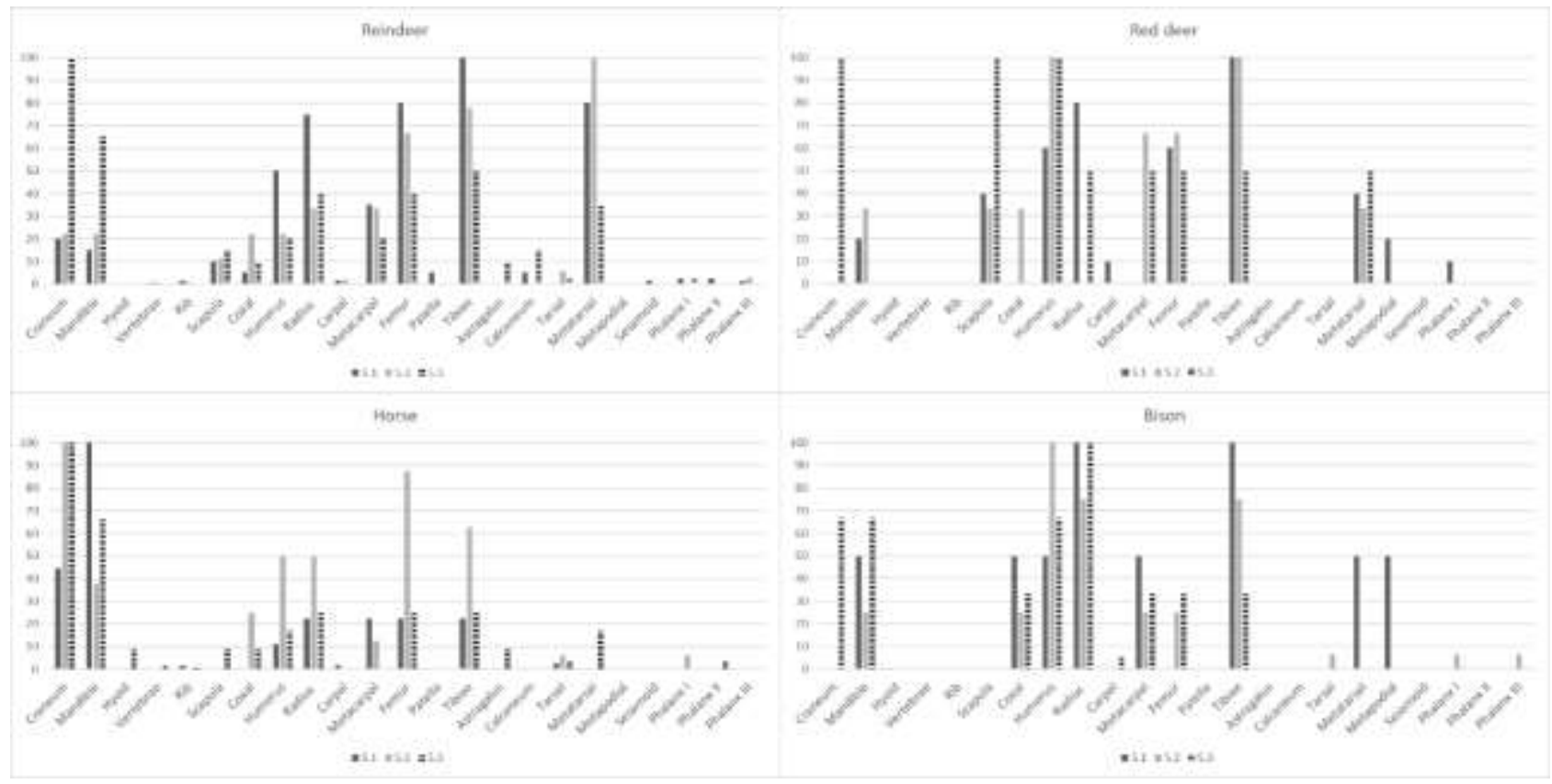

Figure $3 \%$ MAU of the main taxa in levels 5.1, 5.2 and 5.3. Maximum values of MAU: reindeer $(5.1=10 ; 5.2=4.5 ; 5.3=10)$; red deer $(5.1=2.5 ; 5.2=1.5 ; 5.3=1)$; horse $(5.1=4.5 ; 5.2=4 ; 5.3=6)$; bison $(5.1=1 ; 5.2=2 ; 5.3=1.5)$.

The results of statistical correlations between the \%MAU and bone mineral density indicated a highly significant positive correlation for medium-sized animals in the three levels and for largesized animals in levels 5.3. No significant correlations were observed for large-sized animals in levels 5.1 and 5.2 and small animals in the three levels (Table 2).

\begin{tabular}{|l|l|l|l|l|l|l|}
\hline Level & \multicolumn{2}{|l|}{5.1} & \multicolumn{2}{l|}{5.2} & 5.3 \\
\hline Weight size & Spearman's (rs) & $p$ (same) & Spearman's (rs) & $p$ (same) & Spearman's (rs) & $p$ (same) \\
\hline Large size & 0.1653 & 0.10011 & 0.16737 & 0.096024 & 0.30509 & 0.002025 \\
\hline Medium size & 0.3834 & $8.23 \mathrm{e}-05$ & 0.36943 & $1.55 \mathrm{E}-04$ & 0.48893 & $2.45 \mathrm{E}-07$ \\
\hline Small size & 0.042 & 0.67802 & 0.17363 & 0.084048 & 0.001238 & 0.99025 \\
\hline
\end{tabular}

Table 2 Statistical correlation between \%MAU and bone mineral density (Metcalfe and Jones, 1988).

Practically all the specimens in the faunal assemblage were fragmented (5.1=98.2\%/; 5.2=98.6\%; $5.3=93.4 \%$ ). At the three levels most of the remains are smaller than $40 \mathrm{~mm}$, the $50 \%$ of the NSP in 
the level 5.1, the 57\% in level 5.2 and the 50\% in level 5.3 (Figures S1, S2 and S3). Complete elements consist of isolated teeth in the three levels (NR: $5.1=21 ; 5.2=14 ; 5.3=69$ ), followed by articular bones (NR: 5.1=8, 5.2=5; 5.3=10) and the phalanx (NR: 5.1=2; 5.2=2; 5.3=3). In level 5.2, a complete wolf metacarpal was found and in level 5.3, a whole horse atlas and a vestigial metatarsal were recorded. A total of $83.7 \%$ of long bones in level 5.1, the $92.4 \%$ in level 5.2 and the $84.5 \%$ in level 5.3 comprised less than a third of their total circumference and a quarter of their total length (Figure 4). Breakage patterns are similar for the three samples. The most common combination of fracture types are curved, oblique and smooth and longitudinal, oblique and smooth fractures (Figure 4). These indicate that green bone breakage was predominant. Other combinations were also well represented, such longitudinal, right and smooth $(5.1=16.4 \% ; 5.2=10.1 \%$; $5.3=13.1 \%)$, transversal, mixed and irregular $(5.1=10.5 \% ; 5.2=7.3 \% ; 5.3=10 \%)$ (Figure 4).
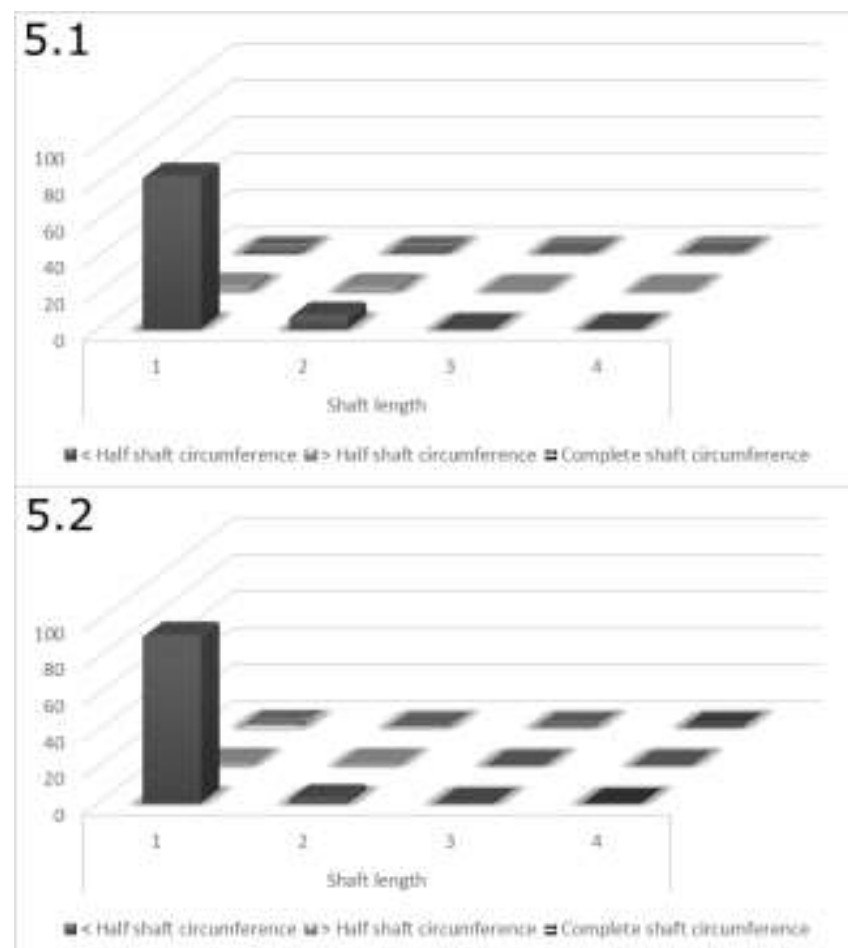

\section{3}

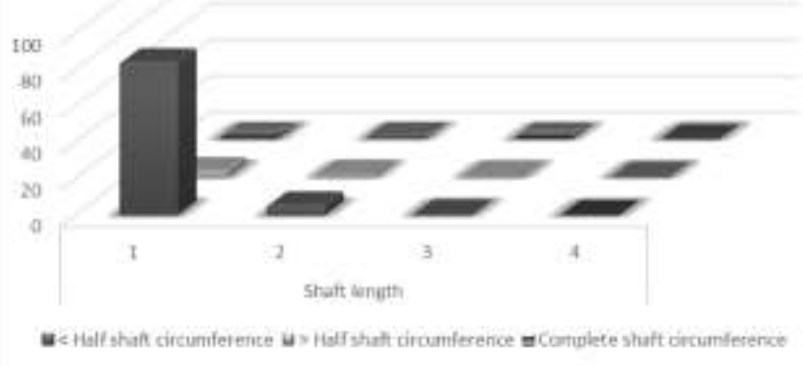

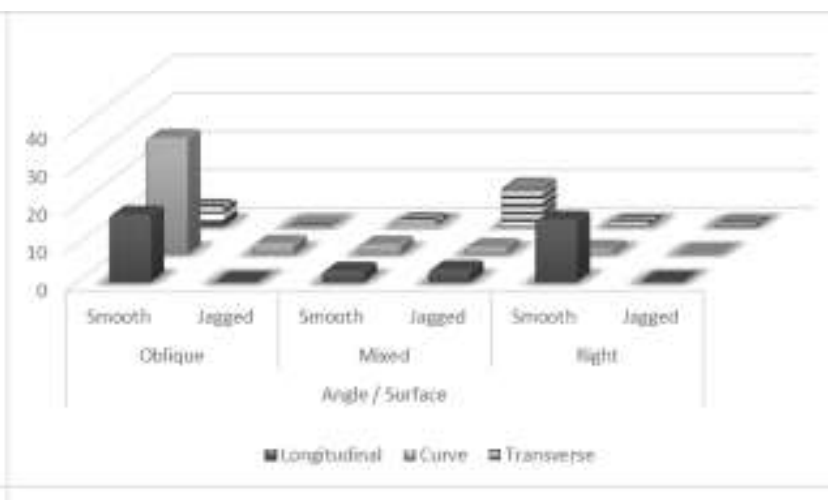
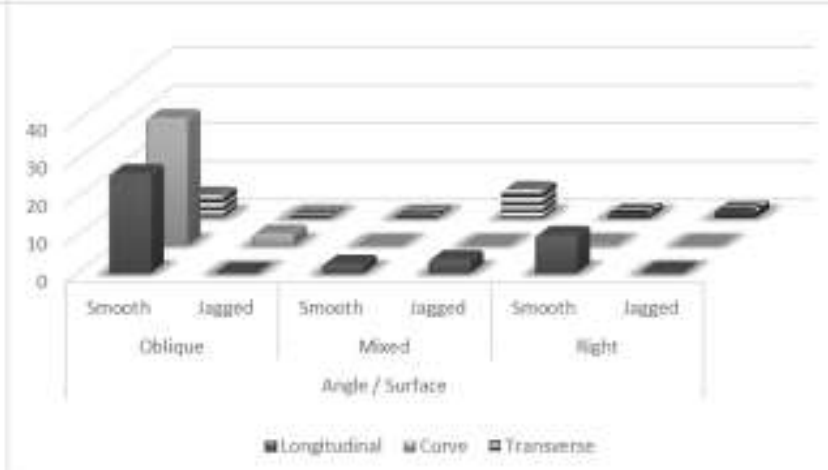

a Longhuninal uCarve a ransaerse

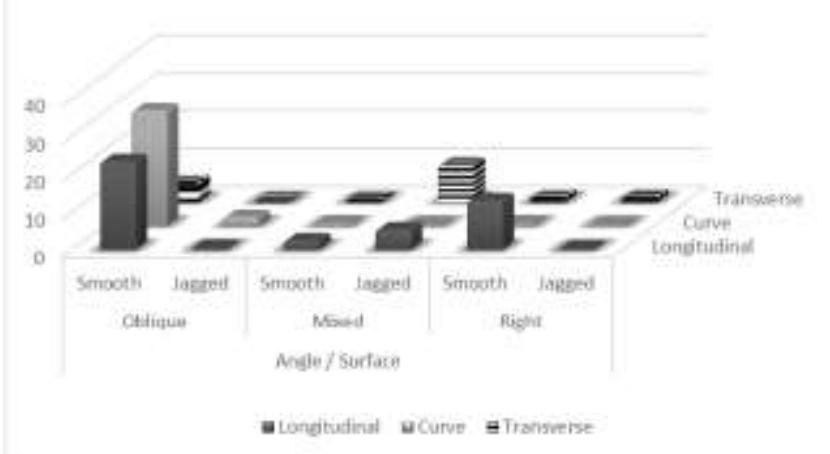

Figure 4 Fragmentation and fracture analysis of long bones for levels 5.1, 5.2 and 5.3. Frequency of the features of fracture planes in long bones (right); Frequency of shaft length and shaft circumference (left). 
The evenness and the SFUI for reindeer indicated the presence of the moderate- and high-utility elements in all levels, specially in level 5.1 (Table 3). In level 5.1, horse elements are represented in proportionate frequencies to their utility. Bison in level 5.2 also show predominant moderate- and high-utility elements (Table 3). The statistical relation between UMI and \%MAU indicates a high and positive relationship for reindeer in the levels 5.1 and 5.2. No statistical correlations were observed for the rest of the assemblages (Table 3).

\begin{tabular}{|c|c|c|c|c|c|c|c|c|}
\hline \multirow[b]{2}{*}{ Levels } & \multirow[b]{2}{*}{ Taxa } & \multirow[b]{2}{*}{ Transport strategies } & \multirow[b]{2}{*}{ NISP } & \multirow{2}{*}{$\begin{array}{l}\text { Evenness } \\
\% \text { MAU }\end{array}$} & \multicolumn{2}{|l|}{ SFUI } & \multicolumn{2}{|l|}{ UMI } \\
\hline & & & & & Spearman's (rs) & $P$ & Spearman's (rs) & $P$ \\
\hline \multirow{4}{*}{5.1} & Reindeer & Bulk & 498 & 0.9287 & 0.83834 & 0.013095 & 0.98561 & 0.0055556 \\
\hline & Red deer & Bulk/Unconstrained & 75 & 0.9443 & 0.74704 & 0.040873 & 0.55078 & 0.2722 \\
\hline & Horse & Unbiased & 72 & 0.867 & -0.45661 & 0.27619 & -0.010142 & 0.86667 \\
\hline & Bison & Bulk/Unconstrained & 19 & 0.9671 & 0.077152 & 0.89524 & 0.24689 & 0.6333 \\
\hline \multirow{4}{*}{5.2} & Reindeer & Bulk & 172 & 0.9193 & 0.62606 & 0.11012 & 0.84067 & 0.04 \\
\hline & Red deer & Bulk/Unconstrained & 33 & 0.9513 & 0.43916 & 0.3 & 0.058849 & 0.9222 \\
\hline & Horse & Bulk/Unconstrained & 52 & 0.9349 & 0.22755 & 0.59048 & 0.28989 & 0.5667 \\
\hline & Bison & Bulk & 18 & 0.9105 & 0.23473 & 0.575 & -0.20597 & 0.7111 \\
\hline \multirow{4}{*}{5.3} & Reindeer & Bulk & 298 & 0.9286 & -0.048196 & 0.9248 & 0.79446 & 0.1 \\
\hline & Red deer & Bulk/Unconstrained & 20 & 0.9708 & -0.068732 & 0.86905 & -0.39279 & 0.6667 \\
\hline & Horse & Bulk/Unconstrained & 115 & 0.8763 & -0.036827 & 0.94107 & 0.61721 & 0.2333 \\
\hline & Bison & Bulk/Unconstrained & 25 & 0.9577 & -0.35044 & 0.40536 & -0.5161 & 0.35 \\
\hline
\end{tabular}

Table 3 Values of Evenness of anatomical distribution and statistical correlation between \%MAU and standard food utility index (SFUI) and unsaturated marrow index (UMI).

\subsection{Mortality profiles}

The estimated MNI for all taxa in level 5.1 was 26 individuals, 16 for level 5.2 and 24 for level 5.3. for reindeer, the MNI was calculated with the tibia in level 5.1, metatarsals in level 5.2 and teeth in 5.3. For red deer, we used tibia in 5.1 and 5.2 and teeth in 5.3. For the horse, teeth were used in all levels. Finally, for bison, the radius was used in levels 5.1 and 5.3 and the humerus in level 5.2. Among the main ungulate taxa, reindeer showed the highest MNI, followed by horse, red deer and bison (Table 4). The rest of the species comprise one wild boar individual in 5.1 and another in 5.2, one individual of roe deer, european ass and rabbit in 5.1, and one fallow deer and a wolf in 5.2.

A total of 79 reindeer teeth $(5.1=10 ; 5.2=14 ; 5.3=55), 96$ horse teeth $(5.1=32 ; 5.2=20 ; 5.3=44), 7$ red deer teeth $(5.1=4 ; 5.2=1 ; 5.3=2)$ and 10 bison teeth $(5.1=4 ; 5.2=0 ; 5.3=6)$ were analysed (Figure 5). The number of analysed teeth found in each level and their integrity (in situ or isolated teeth) are reported in Table 4. The analysis of eruption and replacement rates and wear stages reveal the age of 15 individuals in 5.1, six individuals in level 5.2 and for 24 individuals in 5.3 (Table 4). In all 
three levels, prime adult individuals were the best represented group, followed by juveniles and old individuals.

All the to unfused bones remains taxonomically identified were reindeer. In level 5.1 there were one unfused distal tibia shaft to correspond to a juvenile of one year and one unfused distal radius correspond to a prime adult individual of at least three years. In level 5.2 were identified an unfused distal radius which correspond to a three years old reindeer. In level 5.3 were found a distal tibia shaft and a unfused calcaneum of a young individual of one year and one unfused proximal metacarpal shaft which belonged to an individual of two years.

Reindeer present a prime-dominated profile in all levels. Based on the ternary distribution of Discamps and Costamagno (2015), a prime-dominated profile emerges for levels 5.2 and 5.3. In level 5.1, a juvenile/prime/old profile was observed, with a predominance of prime adult (Figure 6). For horses, a catastrophic mortality profiles was observed for level 5.3 and a prime-dominated profile in levels 5.1 and 5.2. Ternary distribution (Discamps and Costamagno, 2015) presents a juvenile/prime/old profile in all levels (Figure 6). For red deer and bison, prime adult individuals were identified.

\begin{tabular}{|c|c|c|c|c|c|c|c|c|}
\hline \multirow{2}{*}{ Level } & \multirow{2}{*}{ Taxa } & \multirow{2}{*}{ Integrity } & \multirow{2}{*}{ NR } & \multirow{2}{*}{ MNI } & \multicolumn{3}{|c|}{ Age Group } & \multirow{2}{*}{ Indeterminate } \\
\hline & & & & & Juvenile & Prime & Old & \\
\hline \multirow{8}{*}{5.1} & \multirow{2}{*}{ Reindeer } & Isolated tooth & 6 & \multirow{2}{*}{10} & \multirow{2}{*}{1} & \multirow{2}{*}{2} & & \multirow{2}{*}{7} \\
\hline & & Tooth in bone & 4 & & & & & \\
\hline & \multirow{2}{*}{ Red deer } & Isolated tooth & 1 & \multirow{2}{*}{3} & & \multirow{2}{*}{2} & & \multirow{2}{*}{1} \\
\hline & & Tooth in bone & 3 & & & & & \\
\hline & \multirow{2}{*}{ Equus } & Isolated tooth & 17 & \multirow{2}{*}{9} & \multirow{2}{*}{2} & \multirow{2}{*}{6} & \multirow{2}{*}{1} & \\
\hline & & Tooth in bone & 15 & & & & & \\
\hline & \multirow{2}{*}{ Bison } & Isolated tooth & 0 & \multirow{2}{*}{1} & & \multirow{2}{*}{1} & & \\
\hline & & Tooth in bone & 4 & & & & & \\
\hline \multirow{8}{*}{5.2} & \multirow{2}{*}{ Reindeer } & Isolated tooth & 8 & \multirow{2}{*}{5} & & \multirow{2}{*}{2} & & \multirow{2}{*}{3} \\
\hline & & Tooth in bone & 6 & & & & & \\
\hline & \multirow{2}{*}{ Red deer } & Isolated tooth & 1 & \multirow{2}{*}{2} & & & & 2 \\
\hline & & Tooth in bone & \begin{tabular}{|l|}
0 \\
\end{tabular} & & & & & 2 \\
\hline & & Isolated tooth & 11 & 4 & 1 & 3 & & \\
\hline & Equus & Tooth in bone & 9 & 4 & 1 & 3 & & \\
\hline & & Isolated tooth & 0 & 2 & & & & 2 \\
\hline & Bison & Tooth in bone & 0 & 2 & & & & 2 \\
\hline & Reindeer & Isolated tooth & 44 & 13 & 3 & 10 & & \\
\hline & Reindeer & Tooth in bone & 11 & 13 & 3 & 10 & & \\
\hline & & Isolated tooth & 2 & 1 & & & & \\
\hline 53 & Red deer & Tooth in bone & 0 & 1 & & 1 & & \\
\hline 5.3 & Еяния & Isolated tooth & 25 & 8 & 3 & 4 & 1 & \\
\hline & Equus & Tooth in bone & 19 & $\gamma$ & 3 & 4 & 1 & \\
\hline & Bison & Isolated tooth & 2 & 2 & & 2 & & \\
\hline & Bison & Tooth in bone & 4 & 2 & & 2 & & \\
\hline
\end{tabular}

Table 4 Number of teeth analysed by species and their integrity (isolated or within dental series), total minimum number of individuals and minimum number of individuals and age at death in levels 5.1, 5.2 and 5.3.

Based on the analysis of dental eruption and replacement sequences, we assessed the season of death of young individuals. For reindeer, in level 5.1, one individual died in summer (between 1516 months old) and in level 5.3, three young individuals also died in summer (Figure 6). For the 
horse, one individual in level 5.1 died at the end of summer/beginning of autumn, in level 5.2 one individual was killed at the end of spring/beginning of summer and in level 5.3, one individual died at the end of summer/beginning of autumn (Figure 6).

Tooth microwear analysis on reindeer (levels 5.1 and 5.3) and horse (levels 5.1, 5.2, 5.3) shows low SD and CV values, indicating low intra-specific variability (Table 5). Such low values usually correspond to seasonal occupations (Rivals et al. 2015). All the analysed samples plot in area A of the bivariate graph (Figure 7), indicating that the accumulation of the preys in these three levels lasted for three months or less. Additionally, there are no significant differences in variability values among the five samples (Bartlett's K-squared=2.17, $\mathrm{df}=4, p=0.7015$ ), suggesting that the duration of assemblage accumulation is very similar in the three levels.

Microwear values for the reindeer are very similar for the two levels where the sample size was sufficient for microwear analysis, both in terms of pits and scratches. In comparison to microwear data from extant populations of Rangifer tarandus (from Rivals et al. 2015; Rivals and Semprebon 2017), our result correlate well with a summer and early autumn. These microwear results, based on adults, support the results from the dental eruption and replacement sequences (based on young individuals) and confirm that reindeer died in summer. For the horse, no microwear reference data are available for wild equids to test the dental eruption and replacement results. 


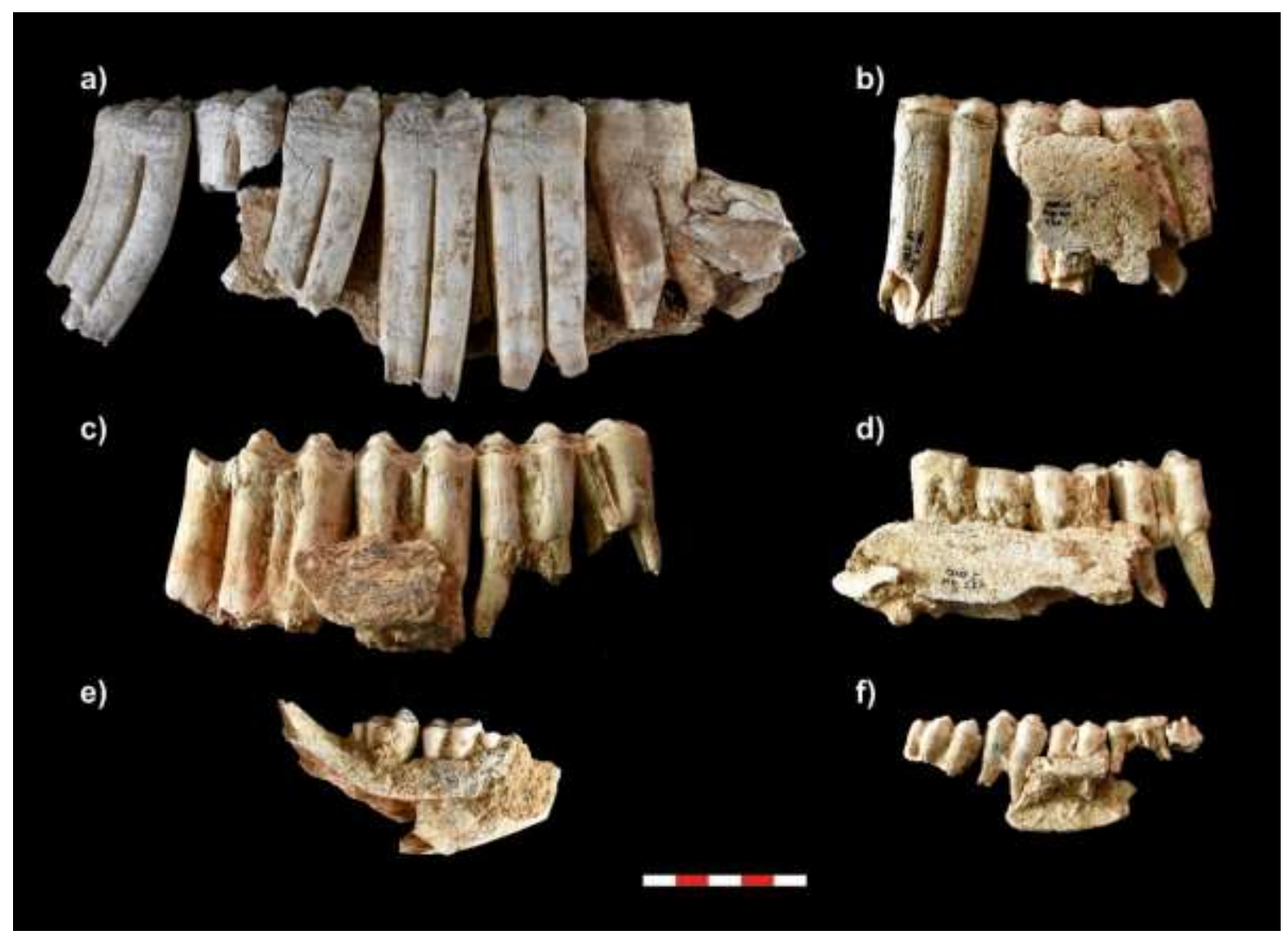

Figure 5 a) and b) mandible refits of fo prime adult horses from levels 5.3 (a) and 5.2 (b); c) and d) bison mandibles of a prime adult from level 5.3; e) reindeer mandible of a prime adult from level 5.3; f) mandible refitting of a reindeer juvenile individual from level 5.1. Scale bar $=5 \mathrm{~cm}$.
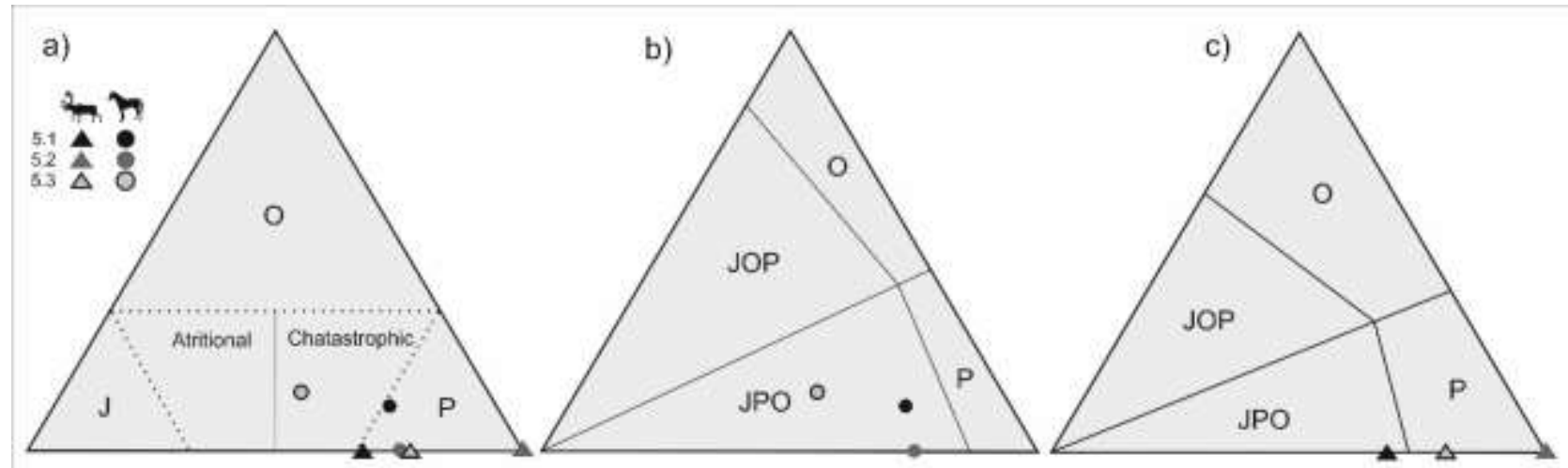

d)

Spring Winter

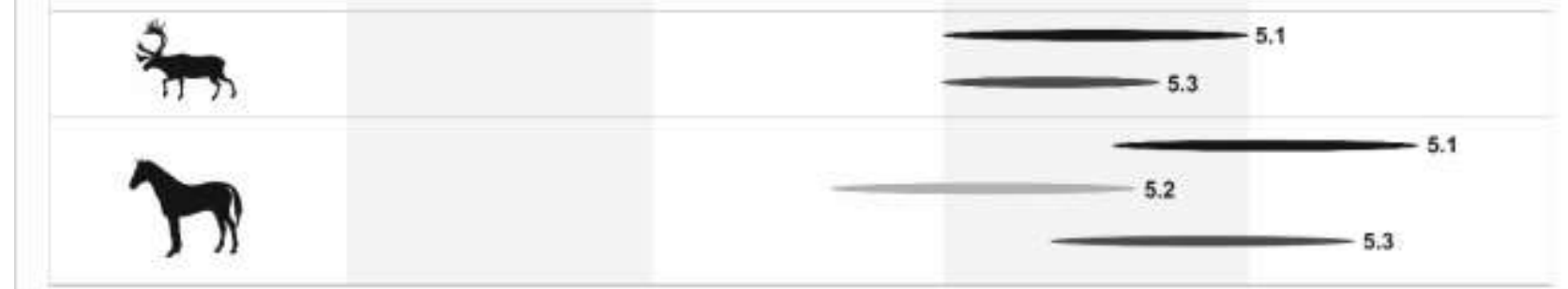

Spring

Summer

Autumn

Figure 6 Ternary plot with mortality profiles for reindeer and horse from levels 5.1 and 5.2. With Stiner (1990) areas (a), and Discamp and Costamagno (2015) areas for the horse (b) and reindeer (c); (d) season of death of young individual of reindeer and horse individuals. 


\begin{tabular}{|l|l|l|l|l|l|l|}
\hline Level & Species & N & NP & NS & CV & SD \\
\hline \multirow{3}{*}{5.1} & E. ferus & 18 & 14.0 & 21.8 & 0.07 & 1.56 \\
\cline { 2 - 7 } & R. tarandus & 6 & 12.3 & 15.8 & 0.13 & 1.97 \\
\hline \multirow{3}{*}{5.2} & E. ferus & 8 & 10.6 & 21.2 & 0.10 & 2.17 \\
\cline { 2 - 7 } & R. tarandus & 1 & - & - & - & - \\
\hline \multirow{3}{*}{5.3} & E. ferus & 14 & 13.9 & 21.6 & 0.09 & 1.90 \\
\cline { 2 - 7 } & R. tarandus & 17 & 13.5 & 15.7 & 0.14 & 2.24 \\
\hline
\end{tabular}

Table 5 Summarized statistics of the dental microwear results for the horse and reindeer from levels 5.1, 5.2 and 5.3 from Abri du Maras. Abbreviations: N = Number of specimens; NP = Mean number of pits; NS = Mean number of scratches; $\mathrm{CV}=\mathrm{Coefficient}$ of Variation of the NS; SD = Standard Deviation of the NS.

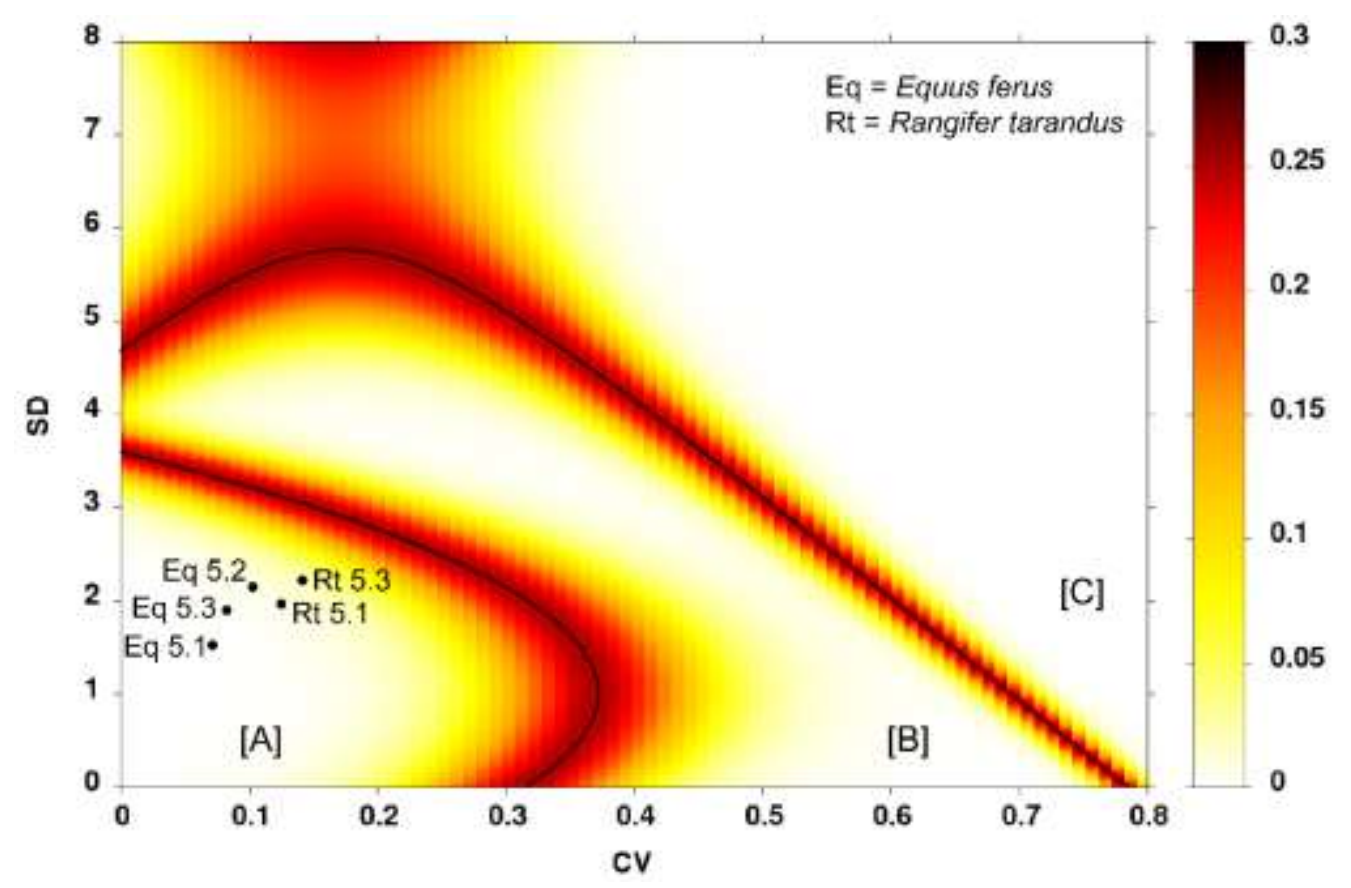

Figure 7 Boundary lines with error probability (heat map) based on SD and CV values of microwear data used for the classification of samples into short events (region A), long-term events (region B), or two separate short events (region C) and positions of the horse and reindeer samples from Abri du Maras levels 5.1, 5.2 and 5.3.

\subsection{Taphonomic signal}

Overall, the visibility of cortical surfaces on the remains from levels 5.1, 5.2 and 5.3 is good. In level 5.1, more than half of the assemblage (67\%) shows good cortical preservation. In level 5.2, the $44 \%$ indicate good preservation and for $41 \%$ two-thirds of the cortical surface were analysable. In level 5.3, the preservation of cortical surfaces was poorer than in the upper levels; $22.6 \%$ of remains show good preservation, for $41.1 \%$, had two-thirds of cortical surfaces were analysable, for $31 \%$, only one-third of the surface was analysable and 5.2\% had none analysable cortical surfaces.

\subsubsection{Post-depositional modifications}

Root marks were the most widespread post-depositional alterations. In level 5.1, 28\% of the remains are affected, $31.7 \%$ in level 5.2 and 52.9\% in level 5.3 (Table 6). Sub-aerial weathering stage 1 were present in the $8 \%$ of the remains of level 5.1 , the $4.4 \%$ of level 5.2 and the $9.2 \%$ of level 5.3. Open-air modifications were higher in level 5.1, which could be related with the external 
area of the rock shelter. Black manganese oxide stains were common on bone surfaces, particularly in level $5.3(22.4 \%)$. On the contrary, orange iron oxide precipitation marks were detected with a low rate of distribution $(5.1=3.8 \% ; 5.2=0.4 \% ; 5.3=2.8 \%)$ (Table 5).

\begin{tabular}{|l|l|l|l|l|l|l|}
\hline NR/\%NR & \multicolumn{2}{|l|}{5.1} & \multicolumn{2}{l}{5.2} & \multicolumn{2}{l|}{5.3} \\
\hline Weathering & 200 & $8.0 \%$ & 62 & $4.4 \%$ & 134 & $9.2 \%$ \\
\hline Roots & 702 & $28 \%$ & 448 & $31.7 \%$ & 772 & $52.9 \%$ \\
\hline Manganese oxide & 306 & $12.2 \%$ & 214 & $15.1 \%$ & 327 & $22.4 \%$ \\
\hline Iron oxide & 96 & $3.8 \%$ & 6 & $0.4 \%$ & 41 & $2.8 \%$ \\
\hline Total NR & 2511 & & 1415 & & 1458 & \\
\hline
\end{tabular}

Table 6 Main post-depositional modifications.

\subsubsection{Anthropogenic modifications}

Anthropogenic modifications are the most common marks resulting from the food processing phase. In level $5.1,8.3 \%$ of the remains bear cut marks, $8.3 \%$ of the remains present percussion marks and $32.8 \%$ show traces of burning. In level 5.2, 5.2\% of bones bear cut marks, $4.1 \%$ of the remains present percussion marks and the $28.3 \%$ show traces of burning. In level 5.3 , the $3.7 \%$ of the remains bear cut marks, $4.3 \%$ of the remains present percussion marks and the $8.6 \%$ show traces of cremations. In addition, we identified 30 remains used as retouchers. Carnivore modifications are extremely scarce and only affect $0.6 \%$ of the bones in level $5.1,0.2 \%$ in level 5.2 and $0.8 \%$ in level 5.3.

The distribution, orientation and types of cut marks provide evidence of the different butchering activities. The most common types of cut marks were slicing, indicating defleshing, followed by skinning, disarticulation and periosteum removal (Table 7). Almost all the cut marks correspond to slicing marks (Figure 8$)$. In addition, scraping marks $(5.1=3.7 \% ; 5.2=1.4 \% ; 5.3=1.6 \%)$ and chopping marks $(5.3=0.4 \%)$ were identified. The taxon with the most cut-marked remains is the reindeer $(5.1=18.3 \% ; 5.2=11 \% ; 5.3=6.7 \%)$, followed by red deer $(5.1=57.6 \% ; 5.2=21.2 \%$; $5.3=15 \%)$, horse $(5.1=11 \% ; 5.2=9.6 \% ; 5.3=2.6 \%)$ and bison $(5.1=31.6 \% ; 5.2=33.3 \% ; 5.3=14.8 \%)$. The comparison of the number of cut-marked remains with the total of NISP indicates that bison and red deer are the species with the highest percentages (Table 6).

Most of the remains with cut marks were long bones (92\% in level 5.1, 88\% in level 5.2 and $73 \%$ in level 5.3), followed by flat bones (7\% in level 5.1, $12 \%$ in level 5.2 and 25\% in level 5.3). A total of $1 \%$ and $2 \%$ of unidentified bones presented cut marks in levels 5.1 and 5.3 respectively. None of the compact bones bear cut marks. In level 5.1, 29\% of upper limb bones, $22.3 \%$ of intermedia limb bones and $12 \%$ of lower limb bones, bear cut marks. In level 5.2, 26.5\% of upper limb bones, $13.6 \%$ of the intermedia limb bones and the $8.8 \%$ of lower limb bones, present cut marks. Finally, 
in level $5.3,7.8 \%$ of upper limb bones, $10 \%$ of the intermedia limb bones and the $8.2 \%$ of lower limb bones, bear cut marks. The total percentage of long bones shaft fragments with cut marks is not high in any of the assemblages (9.3\% in the level 5.1, 5.1\% in level 5.2 and a 3.9\% in level 5.3). The percentage of cut marks on epiphyses is higher (12\% in level 5.1, 9\% in level 5.2 and $11.1 \%$ in level 5.3).

\begin{tabular}{|c|c|c|c|c|c|c|c|c|c|c|c|c|c|c|c|c|c|c|}
\hline \multirow{2}{*}{$\frac{\text { Level }}{\text { Element }}$} & \multicolumn{6}{|l|}{5.1} & \multicolumn{6}{|l|}{5.2} & \multicolumn{6}{|l|}{5.3} \\
\hline & Reindeer & $\begin{array}{l}\begin{array}{l}\text { Red } \\
\text { deer }\end{array} \\
\end{array}$ & Horse & Bison & $\begin{array}{l}\text { Large- } \\
\text { sized }\end{array}$ & $\begin{array}{l}\text { Medium- } \\
\text { sized }\end{array}$ & Reindeer & $\begin{array}{l}\text { Red } \\
\text { deer }\end{array}$ & Horse & Bison & $\begin{array}{l}\text { Large- } \\
\text { sized }\end{array}$ & $\begin{array}{l}\text { Medium- } \\
\text { sized }\end{array}$ & Reindeer & $\begin{array}{l}\text { Red } \\
\text { deer }\end{array}$ & Horse & Bison & $\begin{array}{l}\begin{array}{l}\text { Large- } \\
\text { sized }\end{array} \\
\end{array}$ & $\begin{array}{l}\text { Medium- } \\
\text { sized }\end{array}$ \\
\hline Skull & & & & & & & & & & & $1 / 6$ & & & & & & & \\
\hline$\%$ & & & & & & & & & & & 16.67 & & & & & & & \\
\hline Mandible & $1 / 6$ & & $1 / 10$ & & $1 / 6$ & & & & & $1 / 2$ & $2 / 9$ & & $3 / 21$ & & & & $2 / 15$ & \\
\hline$\%$ & 16.7 & & 10 & & 16.7 & & & & & 50 & 22.2 & & 14.3 & & & & 13.3 & \\
\hline Hyoid & & & & & & & & & & & & & & & $1 / 1$ & & & \\
\hline$\%$ & & & & & & & & & & & & & & & 100 & & & \\
\hline Vertebrae & & & & & & & $1 / 1$ & & & & & & & & $1 / 2$ & & & \\
\hline$\%$ & & & & & & & 100 & & & & & & & & 50 & & & \\
\hline Rib & $1 / 11$ & & $3 / 5$ & & $1 / 7$ & $3 / 46$ & $1 / 2$ & & & & & $2 / 19$ & & & & & $3 / 12$ & $2 / 30$ \\
\hline$\%$ & 9 & & 60 & & 14.2 & 6.52 & 50 & & & & & 10.5 & & & & & 25 & 6.7 \\
\hline Scapula & $1 / 4$ & & & & & & & & & & & & $1 / 5$ & & & & & \\
\hline$\%$ & 25 & & & & & & & & & & & & 20 & & & & & \\
\hline Proximal limb & $29 / 103$ & $4 / 14$ & $1 / 6$ & $2 / 2$ & $3 / 5$ & $1 / 5$ & $6 / 34$ & $2 / 9$ & $4 / 11$ & $4 / 6$ & $1 / 4$ & $1 / 4$ & $2 / 46$ & $2 / 7$ & & $2 / 5$ & & \\
\hline$\%$ & 28.1 & 28.5 & 16.7 & 100 & 60 & 20 & 17.6 & 22.2 & 36.4 & 66.7 & 25 & 25 & 4.3 & 28.6 & & 40 & & \\
\hline $\begin{array}{l}\text { Intermedia } \\
\text { Limb }\end{array}$ & $43 / 207$ & $11 / 32$ & $3 / 11$ & $3 / 11$ & $2 / 12$ & $1 / 11$ & $6 / 52$ & $3 / 10$ & & $1 / 7$ & & & 9/92 & & $1 / 17$ & $2 / 15$ & & $1 / 2$ \\
\hline$\%$ & 20.7 & 34.3 & 27.2 & 27.2 & 16.7 & 9 & 11.5 & 30 & & 14.29 & & & 9.8 & & 5.9 & 13.3 & & 50 \\
\hline Distal limb & $16 / 144$ & $4 / 23$ & & $1 / 4$ & & $2 / 20$ & $5 / 60$ & $2 / 10$ & $1 / 3$ & & & & $5 / 57$ & $1 / 4$ & & & & $1 / 5$ \\
\hline$\%$ & 11.1 & 17.4 & & 25 & & 10 & 8.3 & 20 & 33.3 & & & & 8.8 & 25 & & & & 20 \\
\hline Long bones & & & & & $17 / 141$ & $52 / 542$ & & & & & $8 / 94$ & $19 / 364$ & & & & & $6 / 100$ & $9 / 251$ \\
\hline$\%$ & & & & & 12 & 9.5 & & & & & 8.5 & 5.2 & & & & & 6 & 3.6 \\
\hline Flat bones & & & & & $3 / 24$ & & & & & & $1 / 12$ & & & & & & $1 / 22$ & \\
\hline$\%$ & & & & & 12.5 & & & & & & 8.3 & & & & & & 4.5 & \\
\hline Total & $91 / 490$ & $19 / 74$ & $8 / 39$ & $6 / 19$ & & & $19 / 162$ & $7 / 32$ & $5 / 27$ & $6 / 17$ & & & $20 / 246$ & $3 / 16$ & $3 / 78$ & $4 / 17$ & & \\
\hline$\%$ & 18.5 & 25.6 & 20.5 & 31.6 & & & 11.7 & 22 & 18.5 & 35.2 & & & 8.1 & 18.7 & 3.8 & 23.5 & & \\
\hline
\end{tabular}

Table 7 Number of remains with cut marks, total number and percentage of remains with cut marks by the anatomical element, taxon and weight size category (total number of remains for each taxa excluded the isolated teeth).

The long bones with cut marks show that the butchering processes in level 5.1 were mainly related to flesh removal (78\%), skinning (16\%), periosteum removal (2\%) and disarticulation (1\%). For level 5.2, 70.3\% of the cut marks on long bones indicate defleshing, $21 \%$ skinning, the $5 \%$ disarticulation and $2.7 \%$ periosteum removal. Finally, in level $5.3,74 \%$ of the cut marks on long bones were related to defleshing, $16 \%$ to skinning and $10 \%$ to disarticulation. 


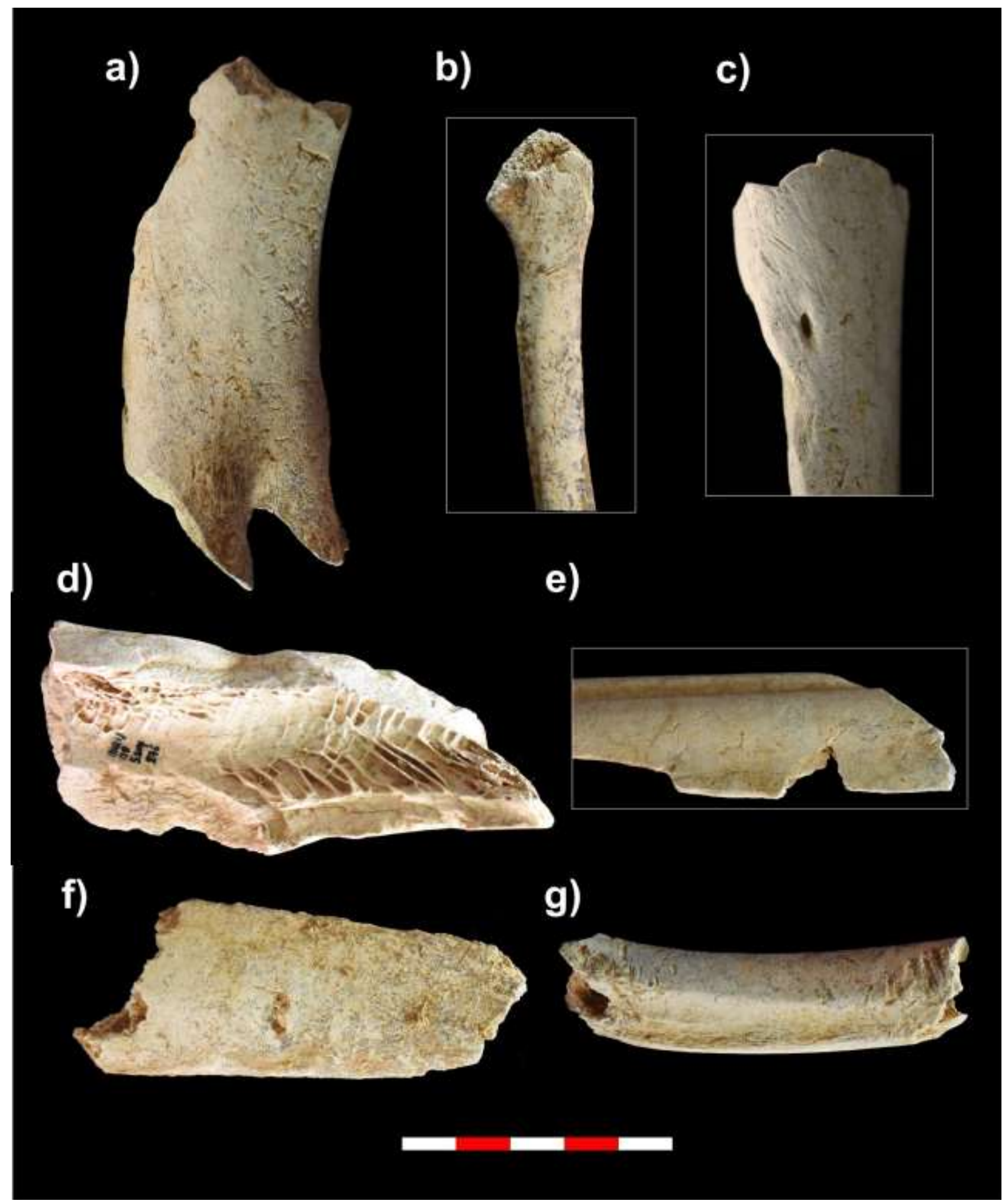

Figure 8 a) fragment of reindeer humerus with cut marks; c) horse hyoid fragment with cut marks; b) reindeer femur fragment with cut marks; d) fragment of reindeer humerus with percussion marks; e) reindeer metatarsal with percussion marks; $f$ ) rib fragment of a large-sized animal with carnivore tooth marks; g) rib fragment of medium-sized animals with carnivore furrowing marks. Scale bar = $5 \mathrm{~cm}$.

A total of 195 remains from level 5.1, 59 remains from 5.2 and 71 from level 5.3 show percussion marks. These were located mainly over long bones (NR: 5.1=194; 5.2=47; 5.3=58) (Figure 8). The remains of medium-sized animals present a higher number of percussion marks than large-sized 
animals. In medium-sized animals, the distribution of percussion marks on long limb bones is more variable in terms of their position on the bone, although there they are more common at mid-shaft. On the large-sized remains, percussion marks are mainly observed on the midshaft portion, except on a radius and tibia from level 5.1 and femurs from levels 5.2 and 5.3.

\begin{tabular}{|c|c|c|c|c|c|c|c|c|c|c|c|c|c|c|c|c|c|c|c|}
\hline \multirow[b]{3}{*}{ Element } & \multirow[b]{3}{*}{ Face } & \multicolumn{9}{|c|}{ Medium-sized } & \multicolumn{9}{|c|}{ Large-sized } \\
\hline & & \multicolumn{3}{|l|}{5.1} & \multicolumn{3}{|l|}{5.2} & \multicolumn{3}{|l|}{5.3} & \multicolumn{3}{|l|}{5.1} & \multicolumn{3}{|l|}{5.2} & \multicolumn{3}{|l|}{5.3} \\
\hline & & $\begin{array}{l}\text { Portion } \\
2\end{array}$ & $\begin{array}{l}\text { Portion } \\
3\end{array}$ & $\begin{array}{l}\text { Portion } \\
4\end{array}$ & $\begin{array}{l}\text { Portion } \\
2\end{array}$ & $\begin{array}{l}\text { Portion } \\
3\end{array}$ & $\begin{array}{l}\text { Portion } \\
4\end{array}$ & $\begin{array}{l}\text { Portion } \\
2\end{array}$ & $\begin{array}{l}\text { Portion } \\
3\end{array}$ & $\begin{array}{l}\text { Portion } \\
4\end{array}$ & $\begin{array}{l}\text { Portion } \\
2\end{array}$ & $\begin{array}{l}\text { Portion } \\
3\end{array}$ & $\begin{array}{l}\text { Portion } \\
4\end{array}$ & Portion 2 & $\begin{array}{l}\text { Portion } \\
3\end{array}$ & $\begin{array}{l}\text { Portion } \\
4\end{array}$ & $\begin{array}{l}\text { Portion } \\
2\end{array}$ & $\begin{array}{l}\text { Portion } \\
3\end{array}$ & $\begin{array}{l}\text { Portion } \\
4\end{array}$ \\
\hline \multirow{4}{*}{ Humerus } & Anterior & 2 & 5 & & & 1 & & & & & & 1 & & & 1 & & & & \\
\hline & Medial & & 3 & 1 & & 1 & & & 2 & & & & & & 1 & & & & \\
\hline & Posterior & & 2 & 1 & & 2 & & & 1 & 1 & & & & & 3 & & & 1 & \\
\hline & Lateral & & 2 & 1 & & 2 & 1 & & 3 & & & & & & & & & & \\
\hline \multirow{4}{*}{ Radius } & Anterior & & 1 & & 1 & 1 & & & 1 & & & 3 & & & 1 & & & 1 & \\
\hline & Medial & & 5 & 1 & & & & & 2 & & & & & & & & & & \\
\hline & Posterior & & 4 & & & & & 1 & & & & 1 & 1 & & & & & & \\
\hline & Lateral & & 2 & & & & & & 1 & & & 1 & & & & & & & \\
\hline \multirow{4}{*}{ Femur } & Anterior & 1 & 6 & 1 & 1 & 2 & & 1 & 1 & & & & & & & & & & \\
\hline & Medial & & 2 & & & 1 & & & 1 & & & & & & & & 1 & & \\
\hline & Posterior & & 5 & 1 & & 1 & 1 & & 3 & & & & & & & & 1 & & 1 \\
\hline & Lateral & & 2 & & & 1 & & & 2 & 1 & & 2 & & & & 1 & & & \\
\hline \multirow{4}{*}{ Tibia } & Anterior & & 5 & 4 & & 1 & 1 & & & 1 & & & & & 1 & & & 1 & \\
\hline & Medial & & 3 & 1 & & & 1 & 1 & 2 & & & 1 & & & & 1 & & & \\
\hline & Posterior & & 7 & 3 & & 2 & 1 & & & 1 & & 3 & 1 & & 1 & & & & \\
\hline & Lateral & 2 & 6 & & & 1 & & & 2 & & 1 & 1 & 1 & & & & & & \\
\hline \multirow{4}{*}{ Metapodials } & Anterior & 2 & 7 & 1 & & 1 & & & & 1 & & & & & & & & & \\
\hline & Medial & & 4 & & & 1 & & & & 2 & & 1 & & & & & & & \\
\hline & Posterior & & 4 & & & 2 & & & & & & 1 & & & & & & & \\
\hline & Lateral & & 8 & & & 1 & & & & 2 & & & & & 1 & & & & \\
\hline
\end{tabular}

Table 8 Number of remains with percussion marks for medium-sized and large-sized animals per long bone element, showing the distribution of impact points on the bone face and portion.

Traces of burning were more abundant in levels 5.1 and 5.2. In level 5.3, they were scarce compared with the overlying levels. Fire damage affects $32.8 \%$ of the remains from level 5.1, $28.3 \%$ from level 5.2 and $8.6 \%$ from level 5.3. All the degrees of burning have been identified (Table 9). In levels 5.1 and 5.2, degree 1 is the most common and the calcinated remains are the least represented. In level 5.3, charred bones (degree 3) are the most frequent. (Table 9). Singlecoloured thermal alterations are prevalent in all levels, whereas double or multiple colourations are relatively rare. In level 5.1, single-coloured alterations account for $87 \%$ and in level 5.2, 90.1\% of the burnt bone sample. Only single-coloured alterations were observed in level 5.3.

\begin{tabular}{|l|l|l|l|l|l|l|}
\hline \multirow{3}{*}{ Levels } & \multicolumn{6}{l|}{ Burned stages } \\
\cline { 2 - 7 } & Unburned & 1 & 2 & 3 & 4 & 5 \\
\hline
\end{tabular}




\begin{tabular}{|l|l|l|l|l|l|l|l|}
\hline \multirow{2}{*}{5.1} & NSP & 1685 & 684 & 339 & 54 & 183 & 3 \\
\cline { 2 - 8 } & $\%$ NSP & 57.2 & 23.2 & 11.5 & 1.8 & 6.2 & 0.1 \\
\hline \multirow{2}{*}{5.2} & NSP & 1015 & 250 & 132 & 206 & 12 & 1 \\
\cline { 2 - 8 } & $\% N S P$ & 62.8 & 15.5 & 8.2 & 12.7 & 0.7 & 0.1 \\
\hline \multirow{2}{*}{5.3} & NSP & 1333 & 43 & 7 & 60 & 16 & 1 \\
\cline { 2 - 8 } & $\% N S P$ & 91.3 & 2.9 & 0.5 & 4.1 & 1.1 & 0.1 \\
\hline
\end{tabular}

Table 9 Number of remains for each degree of burning per level. Remains with more than one code were indicated in each of the corresponding codes. Double colourations were included in each single code of burning.

\subsubsection{Carnivore modifications}

A total of 16 remains from level 5.1 show carnivore modifications, three remains from level 5.2 and 12 from level 5.3. The surface modifications from level 5.1 are pits and punctures $(\mathrm{NR}=11)$, scores $(\mathrm{NR}=5)$, furrowing $(\mathrm{NR}=3)$, crenulated edges $(\mathrm{NR}=3)$ and five remains with cusps on the fractured edge (Figure 8). In level 5.2, punctures $(\mathrm{NR}=2)$ and tooth notches were identified on fractured $(\mathrm{NR}=2)$. In level 5.3, punctures $(\mathrm{NR}=6)$, scores $(\mathrm{NR}=5)$, and furrowing $(\mathrm{NR}=6$ : strong=5; moderate $=1$ ) were observed. The frequency of remains with carnivore modification by weight category shows that medium-sized animals was the most affected (NR: $5.1=11 ; 5.2=3 ; 5.3=8$ ), followed by large animals (NR: $5.1=4 ; 5.3=4)$. Distribution by bone category indicates that tooth marks show similar distributions on long bones $(\mathrm{NR}=9)$ and flat bones $(\mathrm{NR}=8)$ in level 5.1, a higher proportion of flat bones in level 5.2 (NR: long=1; flat=2) and a higher proportion of long bones in level 5.3 (NR: long=9; flat=3). In level 5.1,6\% of the epiphyses bear tooth marks, none in level 5.2, and $8.3 \%$ in level 5.3. The percentage of near epiphyses affected by carnivore activity was smaller; $0.7 \%$ bear tooth marks in level 5.1 and 5.3 and none in level 5.2. Pit measurements were treated statistically for all the shaft fragments from level 5 combined due to the scarcity of measurable modifications in general. The size of the modifications suggests the action of at least one large carnivore (Andrés et al., 2012; Selvaggio and Wilder, 2001) (Figure 9). However, considering the average dimensions of the pit and puncture marks, and their $95 \%$ confidence interval, the small size of the sample did not yield a statistically significant result. 


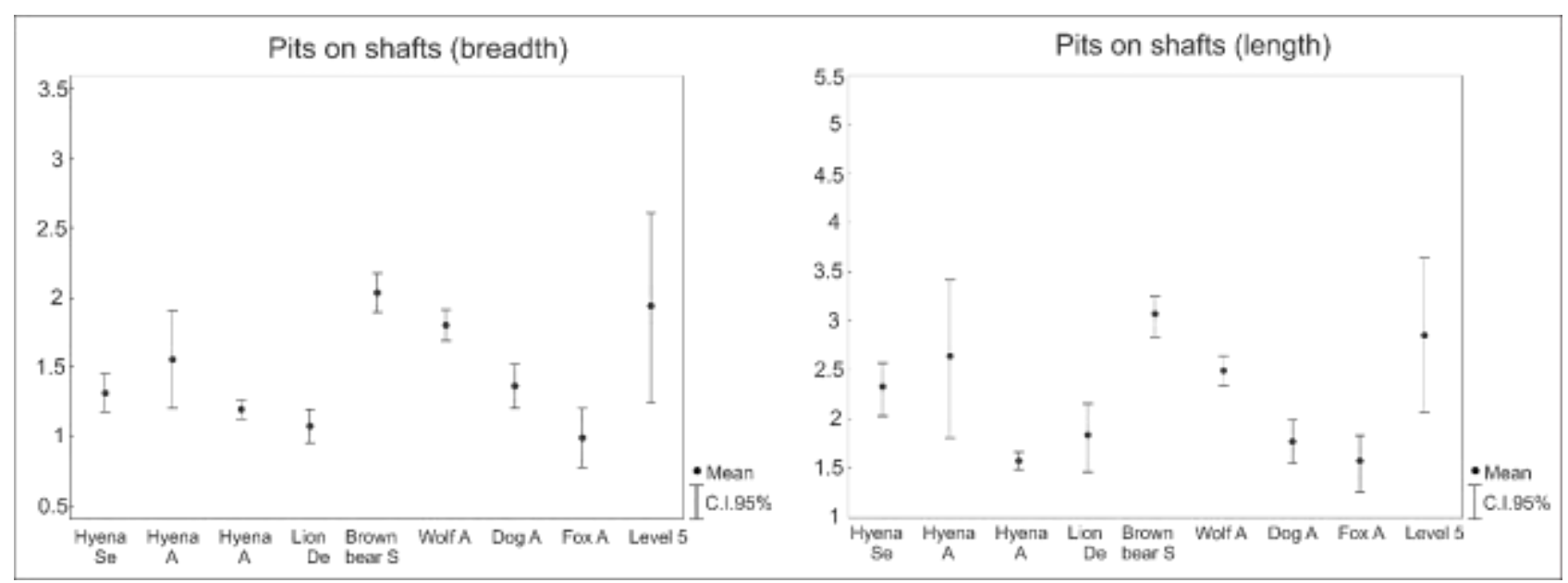

Figure 9 Mean percentages and one standard deviation of tooth pit sizes on dense cortical in function of bone according to their width and length. Data for sampled/specimens marked: Se from Selvaggio (1994); A from Andrés et al. (2012); De from DomínguezRodrigo and Piqueras (2003); S from Saladié et al. (2013). Measures in millimetres (mm).

One remains from level 5.3 presented human and carnivore modification, but with no overlap between them. This was a fragment of a reindeer ulna, with slicing marks on the caudal edge of the olecranon in the midshaft and on the posterior face, which also presents furrowing on the head of the ulna.

\subsection{Bone retouchers}

We identified a total of 30 bone retouchers in level 5 (Figure 10); 18 in level 5.1, 10 in level 5.2 and 2 in level 5.3 (Table 10). In level 5.1, tibia fragments were the most widely used anatomical elements for retouchers with two reindeer remains and one each for bison, horse and red deer. These were followed by two fragments of reindeer femurs and one fragment of a bison humerus. A total of eight unidentified long bone fragments were used as retouchers, six of which belong to large-sized mammals and two to medium-sized animals. In level 5.2, the most commonly used anatomical element was the tibia, with a red deer fragment and a bison fragment. In addition, we identified a horse radius fragment, a reindeer femur, a reindeer metatarsal and a fragment of a large-sized mandible. A total of four unidentified long bone fragments were used as retouchers, three from large animals and one from a medium-sized animal. In level 5.3, only two long bone remains from large animals were used as retouchers. These results indicate that large and medium-sized specimens were used as retouchers in equivalent proportions (NR: 9/9) in level 5.1. Meanwhile, in level 5.2, large-sized remains were more widely used as retouchers than medium-sized remains (NR: 8/3), and in level 5.3, only large-sized remains were used. In general, more long bone fragments were used than flat bones (NR: $5.1=18 / 0 ; 5.2=11 / 1 ; 5.3=2 / 0)$.

\begin{tabular}{|c|c|c|c|c|c|c|c|c|c|c|c|}
\hline \multicolumn{4}{|c|}{ Bone retouchers } & \multicolumn{3}{|c|}{ Type of marks } & \multicolumn{3}{|c|}{ Depth of the marks } & \multirow{2}{*}{ Location of blank } & \multirow{2}{*}{ Position on width } \\
\hline Level & Element & Taxa & NR & Pits & Scores & Areas & I1 & I2 & I3 & & \\
\hline
\end{tabular}




\begin{tabular}{|c|c|c|c|c|c|c|c|c|c|c|c|}
\hline \multirow{9}{*}{5.1} & Humerus & Bison & 2 & Triangular & Rectilinear & Hatched area & & 1 & & Apical & lateral \\
\hline & Femur & Reindeer & 2 & Triangular & Rectilinear & Hatched area & 1 & 2 & & Apical & Lateral/centred \\
\hline & Tibiae & Bison & 1 & Triangular & Rectilinear/rough & Scaled/pitted area & 1 & 1 & & External/centred & Lateral/centred \\
\hline & & Red deer & 2 & Triangular & Rectilinear & Hatched area & 1 & 1 & & Apical/centred & centred \\
\hline & & Horse & 1 & Triangular & Rectilinear & & & 1 & 1 & Covering/centred & Apical/basal \\
\hline & & Reindeer & 2 & Triangular & Rectilinear & Hatched/ pitted area & 1 & 1 & 1 & centred & Apical/basal \\
\hline & Metatarsal & Red deer & 1 & Triangular & Rectilinear & Hatched area & & 1 & & centred & Apical \\
\hline & Long bone & Large size & 6 & Triangular & Rectilinear/smooth & Hatched/pitted/scaled area & 6 & 5 & & Apical/centred/lateral & Apical/basal \\
\hline & & Medium size & 3 & Triangular & Rectilinear & Hatched area & 2 & 2 & & centred & Apical/basal \\
\hline \multirow{8}{*}{5.2} & Mandible & Large size & 1 & Triangular & Rectilinear & Hatched area & 1 & & & centred & centred \\
\hline & Radius-Ulnae & Horse & 1 & Triangular & Rectilinear & Hatched area & 1 & & & Apical & centred \\
\hline & Femur & Reindeer & 1 & Triangular & Rectilinear & Hatched area & 1 & 2 & & Apical & Lateral \\
\hline & Tibiae & Bison & 1 & Triangular & Rectilinear & Hatched area & & 1 & & centred & Apical \\
\hline & & Red deer & 1 & Triangular & Rectilinear & Hatched area & 1 & & & Apical & centred \\
\hline & Metatarsal & Reindeer & 1 & Triangular & Rectilinear & Hatched area & & 1 & & centred & centred \\
\hline & Long bone & Large size & 3 & Triangular & Rectilinear/smooth & Hatched/scaled area & 5 & 4 & & Apical/centred & Apical/basal \\
\hline & & Medium size & 1 & Triangular & Rectilinear & Hatched area & 2 & 2 & & Centred & Apical \\
\hline 5.3 & Long bone & Large size & 2 & Triangular & Rectilinear/smooth & Hatched/pitted area & 1 & 1 & & Apical/centred & Apical/basal \\
\hline
\end{tabular}

Table 10 Number of retouchers and description of used areas and types of modification by anatomical elements and taxon in the three levels.

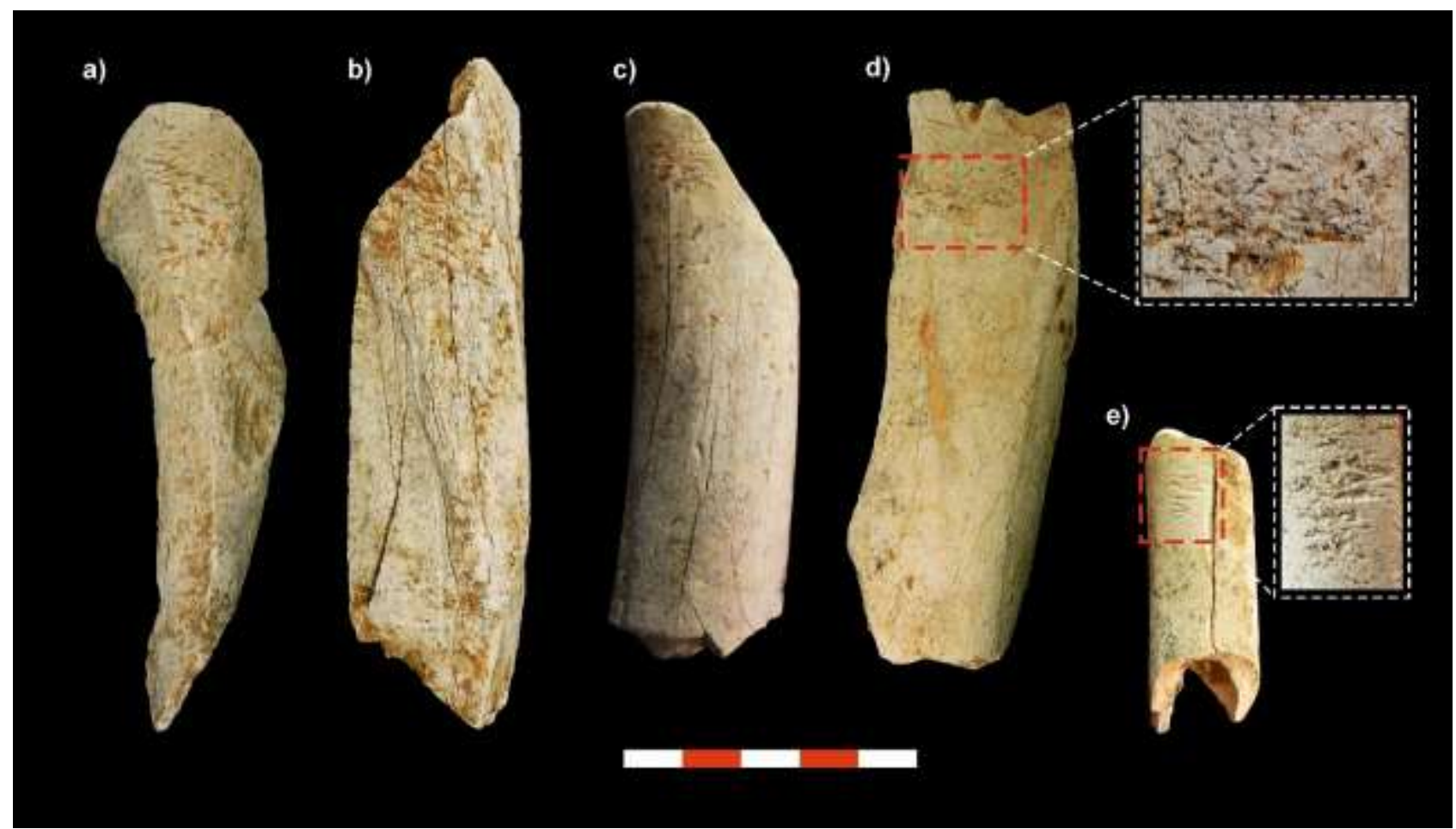

Figure 10 Retoucher from level 5 of Abri du Maras: a) Bison humerus; b) Horse tibia; c) Bison tibia; d) Horse femur; e) Red deer tibia. Scale bar $=5 \mathrm{~cm}$.

\section{Discussion}

In the Abri du Maras sequence, the study of the well-preserved material provides evidence of Neanderthal subsistence in south-eastern of France from the MIS 5 to the end of the MIS 3. The taxonomic diversity of the levels studied here 5.1, 5.2 and 5.3, is similar, between them as indicated 
by the values of Evenness and the Simpson index. The animal spectrum is centred on medium- and large-sized ungulates, a pattern commonly observed in Eurasian Neanderthal assemblages (Adler et al., 2006; Adler and Bar-Oz, 2009; Costamagno et al., 2006; Daujeard and Moncel, 2010; Farizy et al., 1994; Gaudzinski and Roebroeks, 2000; Jaubert and Brugal, 1990; Marín et al., 2017a; Moncel et al., 2004; Patou-Mathis, 2000; Real et al., 2018; Stiner, 1994; Yravedra and Cobo-Sánchez, 2015). In the three levels, large-sized animals were represented exclusively by horse and bison. The giant deer observed in level 4 was not identified in level 5 (Daujeard et al., 2019; Vettese et al., 2017).

The presence of reindeer, horse and bison indicate an open landscape. Taxa typical of forested areas, such as wild boar and roe deer, suggest the exploitation of several biotopes in levels 5.1 and 5.2. The Abri du Maras is located on an ecotone, which enabled the exploitation of the gorge of Ardèche River, the plateaus around the site and the alluvial plains of the Rhône Valley. In addition, this position provided accesses to the plateaus of the farther Massif Central, which was conducive to the exploitation of multiple environments by Neanderthals. In level 4.1 of Abri du Maras, the isotopic results and tooth wear indicated different exploitation areas for red deer and giant deer (forested), on one hand, and horse and reindeer (open lands), on the other (Daujeard et al., 2019). Similar results were shown at the site of Payre (MIS 7-6), further north on the same side of the Rhone valley, where horses were exploited in the valley and deer in the highlands (Ecker et al., 2013; Moncel et al., 2019). However, this assumption should be treated with caution on account of the ecological plasticity of ungulates, which can potentially live in diverse ecosystems and climatic conditions (Discamps et al., 2011).

In order to determine whether an assemblages as results from primary hominin accesses to animal carcasses, Domínguez-Rodrigo (1997) indicated that long bones with cut marks made by flesh removal should account for between $30 \%$ and $60 \%$ of the assemblage. The percentage of cut marks should be higher for proximal appendicular elements than for intermediate elements, which should in turn be higher than for distal elements. In central areas of long bones shafts, the percentage of cut marks should reach more than 43\% (Domínguez-Rodrigo, 1997). In the levels 5.1, 5.2 and 5.3 of the Abri du Maras, most of the cut marks were identified on the long bones. Upper limb bones show a higher percentage of cut marks in levels 5.1 and 5.2 than intermedia limb bones and especially than lower limb bones. In level 5.3, the percentage of cut marks is higher for intermedia and lower limb bones than for upper limbs. More than $70 \%$ of long bones with cut marks in the central diaphysis and were related to defleshing. All these data indicate primary accesses to animal carcasses by hominins (Capaldo, 1998, p. 199; Domínguez-Rodrigo et al., 2007; Lupo and 
O'Connell, 2002; Selvaggio, 1998). The presence of a single carnivore remains, combined with the prevalence of anthropogenic modifications and the scarcity of modifications produced by carnivores and others taphonomic processes, such as hydric flows, show that these three assemblages result from Neanderthal activity. Carnivore activity is limited to scavenging of remains abandoned by humans.

Skeletal profiles in levels 5.1, 5.2 and 5.3 of the Abri du Maras indicated a predominance of long bones over the axial skeleton. The exception was the abundance of cranial remains for reindeer in level 5.3 and for horse in all three levels. These were related to the abundance of mandible and maxilla remains and isolated teeth. Postcranial axial skeleton remains, and compact bones were scarce for all taxa. The comparison of the results of the analysis of bone portions representation with their mineral density suggests differential attrition of the least dense elements. However, the presence of some fragments of postcranial axial skeletons are present for all large-sized and medium-sized taxa, indicating that the trunk was transported some distance from the kill/butchering site. Primary accesses is characterized by the predominance of high-ranked elements with more flesh on them, which is why they were more often transported to the residential site (Binford, 1981, 1978; Bunn and Ezzo, 1993; Domínguez-Rodrigo and Pickering, 2003; Isaac, 1983; Monahan, 1998; O’Connell et al., 1992).

The analysis of transport strategies for reindeer indicated a bulk strategy in all three levels. The bulk strategy is common among present-day hunters-gatherers when demand for meat is high and they need to transport as much mass as possible to the camp (Binford, 1978; Schoville and OtárolaCastillo, 2014). The transport of reindeer carcasses privileged high-value elements in all levels, but heads were more often transported to level 5.3 than to the upper levels of the assemblage. Daujeard et al. (2019) indicated that a deficiency in the presence of isolated teeth and antler in level 4.1 could indicate that the heads were abandoned on the kill site. Often, the lack of skull bones is indicative of increased transport distances (Reynard and Henshilwood, 2017; Schoville and Otárola-Castillo, 2014). Therefore, the abundance of teeth and antler for reindeer and teeth for horse could indicate the opposite scenario, with shorter transport distances. This is all the more likely considering that all the assemblages were affected by differential destruction in the same way.

Anatomical horse profiles were dominated by skull remains in the three levels. However, the statistical analysis indicated an unbiased strategy for horses in level 5.1 and did not give clear results for levels 5.2 and 5.3, indicating a possible unconstrained or bulk strategy, probably related to a statistical error Type II (Faith and Gordon, 2007). Similar high proportions of horse skulls were 
observed in the Aurignacian site of Vogelherd (Niven, 2007). At the latter site, a possible different distance from the kill site (short distance), combined with the major economic utility of heads, may have favoured the transport of horse skulls to the site (Niven, 2007). Hadza groups transport complete zebra carcasses to central places more often than any of the other taxa (Lupo, 2006; Monahan, 1998). Ethnoarchaeological studies indicate that horses skulls were highly valued by hunter-gatherers, for their high quantity of tissues (O'Connell et al., 1988) and because the horse skull was less vulnerable to fat depletion compared to other parts (Levine, 1998; Lupo, 1998; Stiner, 1994). Consequently, the abundance of horse and reindeer heads in level 5.3 could be related to shorter transport distances. However, we must also bear in mind that the transport of heads could possibly represent the cooperative transport of animal carcasses, as demonstrated for other archaeological sites (Marín et al., 2017b; Rodríguez-Hidalgo et al., 2015; Saladié et al., 2011; Stiner, 2013) and by ethnographical studies (Lupo, 2001; Monahan, 1998).

The statistical analysis of the transport of red deer was not resolutive in any of the levels. Anatomical distribution was similar to reindeer distribution, dominated by long limb bones in levels 5.1 and 5.2, and dominated by cranial elements in level 5.3. For bison, the statistical analysis indicated a bulk strategy for level 5.2, but not for levels 5.1 and 5.3. Anatomical distribution was diversified, although long limb bones were abundant in three levels. Therefore, the small assemblage of red deer and bison did not identify a transport strategy in levels, but the anatomical profiles indicated that most of the skeleton parts were transported to the rock shelter at some stage.

Therefore, in the three levels, there is a tendency to transport the elements trying to optimize their economic values. This is particularly true for reindeer in levels 5.1 and 5.2, where the correlation of skeletal profiles and UMI identify a possible preference in the transport of bones in relation to their marrow and mono-unsaturated grease content. Otherwise, for reindeer from level 5.3 and horses, the transport of more complete carcasses may indicate a possible shorter distance to the kill site. In general, hunter-gatherers try the quantity of carcass products discarded at the kill/butchering site and maximize the quantity transported to a central a site (Lupo, 2006).

The identification of primary access, the immediate and recurrent access to large ungulate carcasses has been interpreted as the result of cooperative hunting (Monahan, 1998; Rodríguez-Hidalgo et al., 2015; Saladié et al., 2011; Stiner, 2013; Stiner et al., 2009). Tactical hunts require cooperation between individuals for killing the animals and for storing and transporting the meat (Marean and Assefa, 1999; Monahan, 1998; Saladié et al., 2011; Stiner, 2013). Ju/'hoansi groups increase their chances in ambush hunting events by using cooperative methods (Hitchcock et al., 2019; Lee, 
2012). Hayden (1981) related an increase in cooperation during hunting and meat-sharing in relation with the importance of this resource for the group. Considering the size of some of the preys captured in levels 5.1, 5.2 and 5.3, such as horse or bison, cooperative hunting was likely, as was the cooperative transport of animal carcasses. Monahan (1998) observed that when the Hadza capture a zebra-sized prey, they transport all or almost all of the animal carcass because they can organize large carrying parties. When they capture an animal, they can spend unlimited time at the kill/butchering site, and one of the hunters can stay with the carcass until additional carriers can be located to help with transport, which can require groups of 12 or more adults. In levels 5 , cooperative hunting and cooperative transport strategies, which privileged the transport of elements with high nutritional values, could explain the widespread transport of heads, especially in level 5.3.

The use of certain complementary species in subsistence strategies has been proposed for sites with one predominant taxon, such as the Middle Palaeolithic sites of Jonzac, Les Pradelles, Pech de l'Aze IV and in level 4.1 of Abri du Maras (Costamagno et al., 2006; Daujeard et al., 2019; Niven, 2013; Niven et al., 2012). In the latter assemblage, hunting was centred on reindeer and the capture of horse and bison were secondary (Daujeard et al., 2019). This scenario could be maintained in levels 5.1, 5.2 and 5.3, if we consider the NISP, but differs in respect to the MNI, which is higher for horse and bison than in level 4.1. Similar percentages have been observed in levels Ja and P of Abric Romaní (Marín et al., 2019; Rosell et al., 2012), where red deer reached 50.7\% of the NISP in $\mathrm{Ja}, 63 \%$ in $\mathrm{Pa}$ and $60 \%$ in $\mathrm{Pb}$, as opposed to $35.8 \%$ of the NISP for horse in $\mathrm{Ja}, 22.6 \%$ in $\mathrm{Pa}$ and $32.2 \%$ in $\mathrm{Pb}$, where subsistence is mainly related to the exploitation of these two species.

The results of mortality profile construction indicate a preference for the capture of prime adult individuals for all species, for the three levels. The mortality profiles of reindeer are dominated by prime adults, prime-dominated for horses in levels 5.1 and 5.2 and catastrophic in 5.3. Finally, although red deer and bison individuals are rare, all the animals for which age could be identified were prime adults. Stiner (1990) defines humans as ambush predators with a tendency to systematically capture prime adult individuals. Besides, prime-dominated profiles have been proposed in different ethnoarchaeological and archaeological studies as a result of primary accesses, (Binford, 1978; Bunn and Gurtov, 2014; Bunn and Pickering, 2010a, 2010b; Frison, 1984; Gaudzinski and Roebroeks, 2000; Patou-Mathis, 2000; Stiner, 1990, 2013). Stiner and Kuhn (2006) propose that humans are the only predators who frequently targets the reproductive core of animal populations, this is prime adults. Speth (2019) linked the preference for prime adults, with the highest overall fat levels, to a high dependence on these resource for the calorific supply of Neanderthals groups. Bunn and Gurtov (2014) specify that high rates of prime adults as a result of 
non-selective ambush hunting result in assemblages with more than $70 \%$ of prime adult individuals because prime adult animals predominate in the ecosystem. The mortality profiles identified in this work are dominated by prime adults, with $78.5 \%$ in level $5.1,83.3 \%$ in level 5.2 and a $71 \%$ in level 5.3. These are over the $70 \%$ limit defined by Bunn and Gurtov (2014).

According to the zones developed by Discamps and Costamagno (2015), the reindeer profiles in levels 5.2 and 5.3 indicate prime adults and reindeer in level 5.1 and horse in all levels into the JPO zone, related to L-shaped profiles. However, the JPO zone could not be systematically linked to non-selective hunting, as a result of the variation of the curve of the living-structure profile related to environmental changes or the response to predation pressure (Discamps and Costamagno, 2015). The seasonal data for reindeer suggests a specific capture window during summer for levels 5.1 and 5.3. Unfortunately, there were no data for young reindeer individuals in level 5.2. Data for horse indicated the use of the site during summer in the three levels, although levels 5.1 and 5.3 also point to site use during part of the autumn and level 5.2 for part of spring (Figure 5). Therefore, animals were mainly killed in summer, at a period when ungulate populations comprise a high proportion of juvenile individuals. Levine (1983) indicated that the active hunting of bachelor groups of male horses generated profiles with a higher proportion of prime adults. Although prime adults predominate for the horse in the Abri du Maras, young individuals were also present in the assemblages, especially for in level 5.3, which indicates that groups of females with their foals were also exploited. For reindeer, the predominance of prime adults is even higher than for the horse and they were killed during the same season. Therefore, if hunting was non-selective, we could expect a higher percentage of juvenile reindeer individuals, especially if we consider Damuth's rule which proposes that population densities are inversely related to body size in animal communities (Morin and Ready, 2013). Therefore, these could be related to ambush hunting preferentially killing prime adults. As for the question of whether the prime-dominated profile was the result of selective hunting or simply a statistic issue related to the abundance of prime animals, we opt for a selective tendency, especially in the case of reindeer. For the FLK Zinj assemblage, Bunn and Pickering (2010a) suggest that ambush hunting by projectiles generated a prime-dominated profile. The presence of the projectile technology was clearly identified in the European archaeological record after the discovery of wooden spears at the Middle Pleistocene sites of Schöningen (Schoch et al., 2015; Thieme, 1997) and Clacton-on-Sea (Allington-Jones, 2015; Oakley et al., 1977). This indicates that the spears productions existed in the Neanderthals lineage. This technology was previously identified at Abri du Maras by Hardy et al. (2013) through the study of projectile point fractures. 
A lot of research defines campsites as places where groups generally organized in domestic units live and develop most of their activities (Bartram, 1993; Binford, 1980, 1978; Gamble and Boismier, 1991; Jones, 1983; Kelly, 2013; Kent, 1987; Kroll and Price, 1991; O’Connell et al., 1992, 1988; Yellen, 1977). Isaac's proposals (Isaac, 1978) regarding campsites and livings floors for Pleistocene Hominins are useful for describing Neanderthals sites if we consider the socialrelated aspect. These include the capture of large quantities of meat, for delayed consumption, and transport to a different place, probably at some distance from the kill/butchering site, undoubtedly related to food-sharing events. The occupation of Abri du Maras during the formation of levels 5.1, 5.2 and 5.3 could correspond to the typical features of a residential camp where high quantities of food were transported and processed in situ, during cooperative events. For residential camp, numerous works indicated that intense knapping activities should be expected, generating higher quantities of cores exploitation remains (cortical elements, flakes and core trimming elements) together with less retouched tools (Clark and Barton, 2017; Crater Gershtein et al., 2020; Kuhn, 2013; Vaquero and Romagnoli, 2018). This feature could explain the higher ratio of flake tools and of some Quina scrapers and bifacial scrapers in level 5 of Abri du Maras, made on thin flint slabs collected on the southern plateau. However, we have to consider for the level 5 of the Abri du Maras that the lesser use of the Levallois core technology compared to the above levels 4.1 and 4.2 could explain the higher ratio of flake-tools. In most of European sites and in the surrounding area, the Levallois core technology does not ask to deeply modify the end-products to be efficient (Daujeard and Moncel, 2010; Moncel et al., 2014). Availability of raw materials does not seem to be the reason for explaining a higher intensity of use of the flint resources.

As shown above, levels 5.1, 5.2 and 5.3 were the result of the Neanderthal activity. In the upper levels of Abri du Maras (level 4.1 and 4.2), the accumulations were also described as resulting from Neanderthal activity, with inexistent carnivore activity was inexistent (Daujeard et al., 2019; Vettese et al., 2017). These features have also been identified in other Middle Palaeolithic sites used as residential camps (Cáceres et al., 2012; Castel et al., 2017; Chacón et al., 2010; Gabucio et al., 2014b; Niven, 2013; Real et al., 2018; Yeshurun et al., 2007), where similar accumulations were observed, such as Saint Marcel, where the $40 \%$ of the remains show anthropogenic modifications, or in Baume des Peyrards where $18.2 \%$ of all remains were modified by hominins. In addition, carnivore modifications were particularly rare in these sites (NR\%: Saint Marcel=4\%; Baume des Peyrards $=0.8 \%$ ).

The high degree of burning has been related to high intensity or repeated occupations, whereas low levels of fire damage indicate low intensity occupations (Castel et al., 2017; Costamagno et al., 
2006; Gabucio et al., 2014b; Marín-Arroyo, 2013; Niven et al., 2012). At Wanderer's Cave (Australia), analysis of the burning signal indicated that the majority of the faunal specimens were unintentionally burned (Asmussen, 2009), and that more intensive human occupation led to increased frequencies of thermal modification events. Conversely, short occupation events have been related to less evidence of human occupation or cooking opportunities (Asmussen, 2009). Levels 5.1 and 5.2 comprise a high percentage of burned remains, whereas level 5.3 presents low rates of burning. These could be related to low-intensity occupation in levels 5.3, which could indicate differences between the level 5 occupations, although the taxonomic composition and anthropogenic activities seem to indicate the contrary. We also have to keep in mind that the topographical aspect of the shelter differed over time during the infilling of level 5. The deposit indicates that the shelter was large and possibly extended over two sides of the small valley. Over time, the roof collapsed, and the shelter is now only visible on the right side of the valley. We can infer from quantity of blocks in the level 5 deposit that the shelter roof also slowly decreased in size before the big collapse between levels 4 and 5 .

Long-term occupations usually comprise diversified provisioning strategies over one or several seasons (Audouze, 2010; Bicho and Cascalheira, 2020), whereas short-term occupations show restricted provisioning strategies and multi-seasonal occupations (Costamagno et al., 2006; Martínez-Moreno et al., 2004; Niven et al., 2012; Vallverdú et al., 2005; Villaverde et al., 2017). However, this assumption should be considered carefully, as in some archaeological sites related to short-term occupation events, only one occupation season is observed, such as the French sites of Abri du Maras level 4.1 (Daujeard et al., 2019), les Pradelles (Costamagno et al., 2006), Grotte du Bison (Bouchard, 2016) or Pech de l'Azé IV level 4 (Niven, 2013), or the Spanish sites of Abrigo de la Quebrada (Real et al., 2019). In levels 5.1, 5.2 and 5.3, the site was especially occupied in summer for reindeer, although the horse showed certain variability, including autumn kills in levels 5.1 and 5.3 and spring slaughter in 5.2, and therefore could indicate long-term (seasonal) occupation events. It is important to highlight that young individuals (from dental eruption and replacement patterns) and adults (from tooth microwear) display evidence of the same seasonal dynamic.

Finally, the percentage of retouchers is higher at sites used as residential camps (Daujeard and Moncel, 2010). In level 5.1, the percentage of bone retouchers was $2.6 \%$ and for level 5.2, 1.6\%. In level 5.3, only two retouchers were found. These proportions are similar to those recorded at other MIS 5 sites in region used as long-term campsites, such as of Baume des Peyrards (2\%) or Saint Marcel (3\%). On the other hand, sites from MIS 4 comprise lower percentages of retouchers, such 
as level 4.1 of Abri du Maras (<1\%), Barasses (1\%) or Grotte du Figuier (1\%) (Daujeard and Moncel, 2010).

Ethnoarchaeological studies indicate that the choice of hunting places was generally linked to contexts where prey behaviour could be predicted, such as migration routes, near streams, lakes, springs or ridges, among others (Binford, 1978; Hitchcock et al., 2019). Despite the differences between levels 4.1 and levels 5 of Abri du Maras (Table 11), the repeated use of the site as a campsite indicates the importance of the rock shelter for Neanderthal subsistence strategies. This repeated use may be due to the position of the site which offered refuge and easy accesses to different types of habitats (Daujeard and Moncel, 2010; Moncel and Daujeard, 2012). The results from levels 5.1, 5.2 and 5.3 classify the Abri du Maras level 5 occupation as a residential camp used repeatedly for a complete season, especially in summer, for the exploitation of large ungulates, namely cervids, horse and bison.

\begin{tabular}{|c|c|c|c|c|}
\hline & Level 4.1 & Level 5.1 & Level 5.2 & Level 5.3 \\
\hline Chronology & $\begin{array}{l}40 \pm 3 \text { and } 46 \pm 3 \mathrm{ka}(\mathrm{DO} 12 \\
\text { MIS3) }\end{array}$ & \multicolumn{3}{|c|}{$72 \pm 3 ; 87 \pm 5 ; 89 \pm 4$ and $91 \pm 4 \mathrm{ka}$ (MIS 5) } \\
\hline Identification rate & $12 \%$ & $26.8 \%$ & $19.7 \%$ & $31.5 \%$ \\
\hline $\begin{array}{l}\text { Differential } \\
\text { preservation }\end{array}$ & High positive & High positive & High positive & High positive \\
\hline Diversity taxa & Simpson $=0.81$ & Simpson $=0.57$ & Simpson $=0.46$ & Simpson $=0.48$ \\
\hline $\begin{array}{l}\text { Taxa } \\
\text { representation } \\
\text { NISP\% }\end{array}$ & $\begin{array}{l}\text { Monospecific: } \\
\text { Reindeer: } 88 \% \\
\text { Horse: } 6.4 \% \\
\text { Giant deer: } 1.7 \% \\
\text { Bison: } 0.7 \% \\
\text { Red deer: } 0.5 \% \\
\text { Ibex: } 0.2 \%\end{array}$ & $\begin{array}{l}\text { Diverse: } \\
\text { Reindeer: } 74 \% \\
\text { Red deer: } 11.3 \% \\
\text { Horse: } 10.8 \% \\
\text { Bison: } 2.8 \% \\
\text { Roe deer: } 0.6 \% \\
\text { Ibex:0.3\% } \\
\text { Wild boar: } 0.1 \%\end{array}$ & $\begin{array}{l}\text { Diverse: } \\
\text { Reindeer: } 61.6 \% \\
\text { Red deer: } 11.8 \% \\
\text { Horse: } 18.6 \% \\
\text { Bison: } 6.5 \% \\
\text { Wild boar: } 0.7 \% \\
\text { Fallow deer: } 0.4 \% \\
\text { Wolf: } 0.4 \%\end{array}$ & $\begin{array}{l}\text { Diverse: } \\
\text { Reindeer: } 64.8 \% \\
\text { Red deer: } 4.3 \% \\
\text { Horse: } 25 \% \\
\text { Bison: } 5.9 \%\end{array}$ \\
\hline Weather & $\begin{array}{l}\text { Cold period/humid } \\
\text { peak/cold taxa }\end{array}$ & $\begin{array}{l}\text { Cold taxa/temperate } \\
\text { taxa/forest species }\end{array}$ & $\begin{array}{l}\text { Cold taxa/temperate } \\
\text { taxa/forest species }\end{array}$ & $\begin{array}{l}\text { Cold taxa/temperate } \\
\text { taxa/forest species }\end{array}$ \\
\hline Mortality profiles & Catastrophic reindeer & Prime dominated & Prime dominated & Prime dominated \\
\hline Seasonality & $\begin{array}{l}\text { May/June - fall (only } \\
\text { reindeer). } \\
\text { Two peaks of occupation }\end{array}$ & $\begin{array}{l}\text { Reindeer: Summer } \\
\text { Horse: Autumn/Summer } \\
\text { One long term occupation }\end{array}$ & $\begin{array}{l}\text { Horse: Sumer/Spring } \\
\text { One long term occupation }\end{array}$ & $\begin{array}{l}\text { Reindeer: Summer } \\
\text { Horse: Autumn/Summer } \\
\text { One long term occupation }\end{array}$ \\
\hline $\begin{array}{l}\text { Anatomical } \\
\text { transport }\end{array}$ & $\begin{array}{l}\text { Abundant: Fore-hind } \\
\text { quarters } \\
\text { Scarcity: Heads, trunks, } \\
\text { limb extremities }\end{array}$ & $\begin{array}{l}\text { Abundant: Fore-hind } \\
\text { quarters } \\
\text { Scarcity: Heads, trunks, } \\
\text { limb extremities }\end{array}$ & $\begin{array}{l}\text { Abundant: Fore-hind } \\
\text { quarters } \\
\text { Scarcity: Heads, trunks, } \\
\text { limb extremities }\end{array}$ & $\begin{array}{l}\text { Abundant: Heads, Fore-hind } \\
\text { quarters } \\
\text { Scarcity: Trunks, limb } \\
\text { extremities }\end{array}$ \\
\hline $\begin{array}{l}\text { Human } \\
\text { modifications }\end{array}$ & $\begin{array}{l}\text { Cutmarks: } \\
\text { Rangifer tarandus } 27.7 \% \\
\text { Cervus elaphus } 0 \\
\text { Equus ferus } 30.8 \% \\
\text { Bison priscus } 0 \\
\text { Bone breakage: } 17.7 \%\end{array}$ & $\begin{array}{l}\text { Cutmarks: } \\
\text { Rangifer tarandus } 18.5 \% \\
\text { Cervus elaphus } 25.6 \% \\
\text { Equus ferus } 20.5 \% \\
\text { Bison priscus } 31.6 \% \\
\text { Bone breakage: } 8.3 \%\end{array}$ & $\begin{array}{l}\text { Cutmarks: } \\
\text { Rangifer tarandus } 11.7 \% \\
\text { Cervus elaphus } 22 \% \\
\text { Equus ferus } 18.5 \% \\
\text { Bison priscus } 35.2 \% \\
\text { Bone breakage: } 6.5 \%\end{array}$ & $\begin{array}{l}\text { Cutmarks: } \\
\text { Rangifer tarandus } 8.1 \% \\
\text { Cervus elaphus } 18.7 \% \\
\text { Equus ferus } 3.8 \% \\
\text { Bison priscus } 23.5 \% \\
\text { Bone breakage: } 4.3 \%\end{array}$ \\
\hline
\end{tabular}




\begin{tabular}{|c|c|c|c|c|}
\hline & Burned: $20.7 \%$ & Burned: $32.8 \%$ & Burned: $28.3 \%$ & Burned: $8.6 \%$ \\
\hline Bone retouchers & $\mathrm{NR}=1$ & $\mathrm{NR}=18$ & $\mathrm{NR}=10$ & $\mathrm{NR}=2$ \\
\hline $\begin{array}{l}\text { Human } \\
\text { occupation }\end{array}$ & $\begin{array}{l}\text { Short-term planned hunting } \\
\text { activity } \\
\text { Communal mass hunting }\end{array}$ & $\begin{array}{l}\text { Seasonal campsite for } \\
\text { long-term occupation } \\
\text { events } \\
\text { Selective ambush hunting }\end{array}$ & $\begin{array}{l}\text { Seasonal campsite for long- } \\
\text { term occupation events } \\
\text { Selective ambush hunting }\end{array}$ & $\begin{array}{l}\text { Seasonal campsite for long- } \\
\text { term occupation events } \\
\text { Selective ambush hunting }\end{array}$ \\
\hline
\end{tabular}

Table 11 Principal features of Abri du Maras levels 4.1, 5.1, 5.2 and 5.3.

\section{Conclusions}

Our result offers a view of the occupation dynamics and subsistence strategies developed by Neanderthals at the Abri du Maras during the formation of level 5, which permit a comparison with other sites of the region and the upper levels 4.1 and 4.2 of Abri du Maras. As a result of our analysis, we can confirm that during the formation of levels 5.1, 5.2 and 5.3, Neanderthal groups used the Abri du Maras rock shelter as a seasonal campsite for long-term occupation events, especially in summer. The taxonomical distribution in level 5 could indicate a more temperate climate, with the presence of forest species, and an open landscape, with taxa typical of plains. Neanderthals intensively exploited faunal resources around the shelter, located in a small valley close to the Ardèche River. The type of occupation, i.e., a long-term residential habitat, appears different from that of level 4.1 (MIS 3), which highlights short-term episodes of reindeer hunting. In level 5, the lithic assemblage shows a higher ratio of flake tools, including some large scrapers, possibly a limited introduction of already worked products and a higher quantity of whole pebbles in diverse stones collected along the Ardèche River. They indicate strategies adapted to long-term occupations with various domestic activities. Mortality profiles indicate preferential selection of prime-dominated reindeer, red deer and horse, mainly killed during the summer. However, horses were also killed during the autumn, which could indicate different seasonal events. Our data indicate that the most probable hunting strategy was cooperative ambush hunting. After capture, the transport of animal carcasses optimizes the food values of the transported elements, which is a typical pattern for sites used as residential camps. However, the high percentage of cranial remains for reindeer in level 5.3 and horses in all levels seems to indicate that the transport distance or the number of carriers facilitated the repeated transport of this anatomical element. The different use of the Abri du Maras as a residential campsite for long-term occupation events in level 5 compared with the upper level 4.1 related with a specialized and short-term occupation events, allows us to recognize different models of occupation and exploitation of the territory developed by Neanderthal groups from the end of MIS 5 to MIS 3. 


\section{Acknowledgment}

Fieldwork at Abri du Maras was supported by the Ministry of Culture, Service régional de l'archéologie Auvergne-Rhône-Alpes. Juan Marín is the beneficiary of an Erasmus Mundus Doctoral scholarship for International Doctorate in Quaternary and Prehistory. A.R.-H. is the beneficiary of a postdoctoral scholarship from the MICIIN, Subprograma Juan de la Cierva (IJC037447-I). We thank the editor José Carrión and the anonymous reviewers for their help and suggestions that improved the original version of the manuscript. We thank L. Byrne for their English form edition of the manuscript.

\section{Bibliography}

Abe, Y., 2005. Hunting and butchery patterns of the Evenki in Northern Transbaikalia, Russia. Stony Brook.

Adler, D.S., Bar-Oz, G., 2009. Seasonal Patterns of Prey Acquisition and Inter-group Competition During the Middle and Upper Palaeolithic of the Southern Caucasus, in: Hublin, J.-J., Richards, M.P. (Eds.), The Evolution of Hominin Diets: Integrating Approaches to the Study of Palaeolithic Subsistence. Springer, Dordrecht, pp. 127-140. https://doi.org/10.1007/978-1-4020-9699-0_9

Adler, D.S., Bar-Oz, G., Belfer-Cohen, A., Bar-Yosef, O., 2006. Ahead of the Game: Middle and Upper Palaeolithic Hunting Behaviors in the Southern Caucasus. Curr. Anthropol. 47, 89118. https://doi.org/10.1086/432455

Allington-Jones, L., 2015. The Clacton Spear: The Last One Hundred Years. Archaeol. J. 172, 273296. https://doi.org/10.1080/00665983.2015.1008839

Andrés, M., Gidna, A.O., Yravedra, J., Domínguez-Rodrigo, M., 2012. A study of dimensional differences of tooth marks (pits and scores) on bones modified by small and large carnivores. Archaeol. Anthropol. Sci. 4, 209-219. https://doi.org/10.1007/s12520-012-00934

Asmussen, B., 2009. Intentional or incidental thermal modification? Analysing site occupation via burned bone. J. Archaeol. Sci. 36, 528-536. https://doi.org/10.1016/j.jas.2008.10.005

Audouze, F., 2010. Domesticity and spatial organization at Verberie, in: The Magdalenian Household: Unraveling Domesticity. Estate University of New York, Albany, New York, pp. 145-175.

Azorit, C.A., 2011. Guía para la determinación de la edad del ciervo ibérico (Cervus elaphus hispanicus) a través de su dentición: revisión metodológica y técnicas de elección. An. Real Acad. Cienc. Vet. Andal. Orient. 24 235-264 2011.

Barone, R., 1976. Anatomie comparée des mammifères domestiques. Tome 1: Ostéologie. Vigot frères, Paris.

Bartram, E., 1993. An ethnoarchaeological analysis of Kua San (Botswana) bone food refuses. University of Wisconsin, Madison.

Behrensmeyer, A.K., 1978. Taphonomic and ecologic information from bone weathering. Paleobiology 4, 150-162. https://doi.org/10.1017/S0094837300005820

Bicho, N., Cascalheira, J., 2020. Use of Lithic Assemblages for the Definition of Short-Term Occupations in Hunter-Gatherer Prehistory, in: Cascalheira, J., Picin, A. (Eds.), Short-Term Occupations in Paleolithic Archaeology: Definition and Interpretation. Springer International Publishing, Cham, pp. 19-38. https://doi.org/10.1007/978-3-030-27403-0_2 
Bignon, O., 2006. Approche morphométrique des dents jugales déciduales d'Equus caballus arcelini (sensu lato, Guadelli 1991): critères de détermination et estimation de l'âge d'abattage. Comptes Rendus Palevol 5, 1005-1020. https://doi.org/10.1016/j.crpv.2006.09.004

Binford, L.R., 1984. Faunal remains from Klassies River Mouth. Academic Press, New York.

Binford, L.R., 1981. Bones: Ancient men and modern myths, First Edition edition. ed. Academic Press, New York.

Binford, L.R., 1980. Willow Smoke and Dogs' Tails: Hunter-Gatherer Settlement Systems and Archaeological Site Formation. Am. Antiq. 45, 4-20. https://doi.org/10.2307/279653

Binford, L.R., 1978. Nunamiut Ethnoarchaeology. Academic Press, New York, NY.

Blumenschine, R.J., 1995. Percussion marks, tooth marks, and experimental determinations of the timing of hominid and carnivore access to long bones at FLK Zinjanthropus, Olduvai Gorge, Tanzania. J. Hum. Evol. 29, 21-51. https://doi.org/10.1006/jhev.1995.1046

Blumenschine, R.J., Selvaggio, M.M., 1988. Percussion marks on bone surfaces as a new diagnostic of hominid behaviour. Nature 333, 763-765. https://doi.org/10.1038/333763a0

Bocherens, H., 2011. Diet and Ecology of Neanderthals: Implications from C and N Isotopes, in: Conard, N.J., Richter, J. (Eds.), Neanderthal Lifeways, Subsistence and Technology: One Hundred Fifty Years of Neanderthal Study. Springer Netherlands, Dordrecht, pp. 73-85. https://doi.org/10.1007/978-94-007-0415-2_8

Bocherens, H., Díaz-Zorita Bonilla, M., Daujeard, C., Fernandes, P., Raynal, J.-P., Moncel, M.-H., 2016. Direct isotopic evidence for subsistence variability in Middle Pleistocene Neanderthals (Payre, southeastern France). Quat. Sci. Rev. 154, 226-236. https://doi.org/10.1016/j.quascirev.2016.11.004

Bouchard, G., 2016. Grotte du Bison: deux chasseurs pour un gibier: analyse archéozoologique de la couche IJ sur le site moustérien de la Grotte du Bison, Arcy-sur-Cure (Yonne, France).

Bouchud, J., 1966. Essai sur le Renne et la climatologie du Paléolithique supérieur. Magne.

Boulbes, N., van Asperen, E.N., 2019. Biostratigraphy and Palaeoecology of European Equus. Front. Ecol. Evol. 7, 301. https://doi.org/10.3389/fevo.2019.00301

Boyle, K.V., 2000. Reconstructing Middle Palaeolithic subsistence strategies in the South of France. Int. J. Osteoarchaeol. 10, 336-356. https://doi.org/10.1002/10991212(200009/10)10:5<336::AID-OA560>3.0.CO;2-5

Brown, W.A.B., Chapman, N.G., 1991. The dentition of red deer (Cervus elaphus): a scoring scheme to assess age from wear of the permanent molariform teeth. J. Zool. 224, 519-536. https://doi.org/10.1111/j.1469-7998.1991.tb03783.x

Brugal, J.-P., 2001. Les assemblages fauniques : paléoenvironnement, taphonomie et archéozoologie. Un Site Moustérien Type Quina Dans Val. Celé Pailhès À Espagnac-SainteEulalie 33-52.

Bunn, H.T., 1981. Archaeological evidence for meat-eating by Plio-Pleistocene hominids from Koobi Fora and Olduvai Gorge. Nature 291, 574-577. https://doi.org/10.1038/291574a0

Bunn, H.T., Ezzo, J.A., 1993. Hunting and Scavenging by Plio-Pleistocene Hominids: Nutritional Constraints, Archaeological Patterns, and Behavioural Implications. J. Archaeol. Sci. 20, 365-398. https://doi.org/10.1006/jasc.1993.1023

Bunn, H.T., Gurtov, A.N., 2014. Prey mortality profiles indicate that Early Pleistocene Homo at Olduvai was an ambush predator. Quat. Int. 322-323, 44-53. https://doi.org/10.1016/j.quaint.2013.11.002

Bunn, H.T., Pickering, T.R., 2010a. Bovid mortality profiles in paleoecological context falsify hypotheses of endurance running-hunting and passive scavenging by early Pleistocene hominins. Quat. Res. 74, 395-404. https://doi.org/10.1016/j.yqres.2010.07.012

Bunn, H.T., Pickering, T.R., 2010b. Methodological recommendations for ungulate mortality analyses in paleoanthropology. Quat. Res. 74, 388-394.

https://doi.org/10.1016/j.yqres.2010.07.013 
Burke, A., 2002. Palaeoethology as an archaeological tool: a model for the social and spatial behaviour of E. hydruntinus, in: Equids in Time and Space Papers in Honour of Véra Eisenmann. Presented at the Proceedings of the 9th Conference of the International Council of Archaeozoology, Durham, August 2002 Series Editors: Umberto Albarella, Keith Dobney and Peter Rowley-Conwy, Oxbow Books, Park End Place, Oxford, pp. 62-69.

Burke, A., 2000. The view from Starosele: faunal exploitation at a middle palaeolithic site in western Crimea. Int. J. Osteoarchaeol. 10, 325-335. https://doi.org/10.1002/10991212(200009/10)10:5<325::AID-OA556>3.0.CO;2-T

Cáceres, I., 2002. Tafonomía de yacimientos antrópicos en karst. Complejo Galería (Sierra de Atapuerca, Burgos), Vanguard Cave (Gibraltar) y Abric Romaní (Capellades, Barcelona). Universitat Rovira i Virgili, Tarragona.

Cáceres, I., Bennàsar, M., Huguet, R., Rosell, J., Saladié, P., Allué, E., Solé, A., Blasco, R., Campeny, G., Esteban-Nadal, M., Fernández-Laso, C., Gabucio, M.J., Ibáñez, N., Martín, P., Muñoz, L., Rodríguez-Hidalgo, A., 2012. Taphonomy of Level J of Abric Romaní, in: Carbonell i Roura, E. (Ed.), High Resolution Archaeology and Neanderthal Behavior: Time and Space in Level J of Abric Romaní (Capellades, Spain). Springer Netherlands, Dordrecht, pp. 159-185. https://doi.org/10.1007/978-94-007-3922-2_6

Capaldo, S.D., 1998. Methods, marks, and models for inferring hominid and carnivore behavior. J. Hum. Evol. 35, 317-320. https://doi.org/10.1006/jhev.1998.0242

Capaldo, S.D., Blumenschine, R.J., 1994. A Quantitative Diagnosis of Notches Made by Hammerstone Percussion and Carnivore Gnawing on Bovid Long Bones. Am. Antiq. 59, 724-748. https://doi.org/10.2307/282345

Carrión, J.S., Walker, M.J., 2019. Background to Neanderthal presence in Western Mediterranean Europe. Neanderthals Ecol. Evol. 217, 7-44. https://doi.org/10.1016/j.quascirev.2018.10.011

Castel, J.-C., Discamps, E., Soulier, M.-C., Sandgathe, D., Dibble, H.L., McPherron, S.J.P., Goldberg, P., Turq, A., 2017. Neandertal subsistence strategies during the Quina Mousterian at Roc de Marsal (France). Quat. Int. 433, 140-156. https://doi.org/10.1016/j.quaint.2015.12.033

Chacón, M.G., Fernández-Laso, M.C., Rivals, F., 2010. Comportements des populations néandertaliennes pendant le MIS 3 à l'Abric Romaní: Les niveaux K, L et M. Variabilité ou continuité?, in: Transitions, Ruptures et Continuité En Préhistoire. Bordeaux-Les Eyzies, pp. 07-228.

Clark, G.A., Barton, C.M., 2017. Lithics, landscapes \& la Longue-durée - Curation \& expediency as expressions of forager mobility. Prehist. Hunt.-Gatherers Farmers Adriat. Neighboring Reg. 450, 137-149. https://doi.org/10.1016/j.quaint.2016.08.002

Combier, J., 1967. Le Paléolithique de l'Ardèche dans son cadre bioclimatique. Delmas, Bordeaux.

Costamagno, S., Liliane, M., Cédric, B., Bernard, V., Bruno, M., 2006. Les Pradelles (Marillac-leFranc, France): A mousterian reindeer hunting camp? J. Anthropol. Archaeol. 25, 466-484. https://doi.org/10.1016/j.jaa.2006.03.008

Crater Gershtein, K.M., Zaidner, Y., Yeshurun, R., 2020. A campsite on the open plain: Zooarchaeology of Unit III at the Middle Paleolithic site of Nesher Ramla, Israel. Quat. Int. https://doi.org/10.1016/j.quaint.2020.01.026

Daujeard, C., 2008. Exploitation du milieu animal par les Néanderthaliens dans le Sud-Est de la France (thesis). Lyon 2.

Daujeard, C., Moncel, M.-H., 2010. On Neanderthal subsistence strategies and land use: A regional focus on the Rhone Valley area in southeastern France. J. Anthropol. Archaeol. 29, 368391. https://doi.org/10.1016/j.jaa.2010.05.002

Daujeard, C., Moncel, M.-H., Fiore, I., Tagliacozzo, A., Bindon, P., Raynal, J.-P., 2014. Middle Paleolithic bone retouchers in Southeastern France: Variability and functionality. Eur. 
Middle Palaeolithic MIS 8 - MIS 3 Cult. Environ. Chronol. 326-327, 492-518. https://doi.org/10.1016/j.quaint.2013.12.022

Daujeard, C., Vettese, D., Britton, K., Béarez, P., Boulbes, N., Crégut-Bonnoure, E., Desclaux, E., Lateur, N., Pike-Tay, A., Rivals, F., Allué, E., Chacón, M.G., Puaud, S., Richard, M., Courty, M.-A., Gallotti, R., Hardy, B., Bahain, J.J., Falguères, C., Pons-Branchu, E., Valladas, H., Moncel, M.-H., 2019. Neanderthal selective hunting of reindeer? The case study of Abri du Maras (south-eastern France). Archaeol. Anthropol. Sci. 11, 985-1011.

Debard, E., 1988. Le quaternaire du Bas-Vivarais d'apráes l'âetude des remplissages d'avens, de porches de grottes et d'abris sous roche: dynamique sâedimentaire, palâeoclimatologie et chronologie. Dâepartement des sciences de la terre, Universitâe Claude-Bernard.

Delagnes, A., Jaubert, J., Meignen, L., 2007. Les technocomplexes du Paléolithique moyen en Europe occidentale dans leur cadre diachronique et géographique.

Delagnes, A., Meignen, L., 2006. Diversity of Lithic Production Systems During the Middle Paleolithic in France, in: Hovers, E., Kuhn, S.L. (Eds.), Transitions Before the Transition: Evolution and Stability in the Middle Paleolithic and Middle Stone Age. Springer US, Boston, MA, pp. 85-107. https://doi.org/10.1007/0-387-24661-4_5

Delagnes, A., Rendu, W., 2011. Shifts in Neandertal mobility, technology and subsistence strategies in western France. J. Archaeol. Sci. 38, 1771-1783. https://doi.org/10.1016/j.jas.2011.04.007

Dibble, H.L., 1995. Middle paleolithic scraper reduction: Background, clarification, and review of the evidence to date. J. Archaeol. Method Theory 2, 299-368. https://doi.org/10.1007/BF02229003

Discamps, E., Costamagno, S., 2015. Improving mortality profile analysis in zooarchaeology: a revised zoning for ternary diagrams. J. Archaeol. Sci. 58, 62-76. https://doi.org/10.1016/j.jas.2015.03.021

Discamps, E., Jaubert, J., Bachellerie, F., 2011. Human choices and environmental constraints: deciphering the variability of large game procurement from Mousterian to Aurignacian times (MIS 5-3) in southwestern France. Quat. Sci. Rev. 30, 2755-2775. https://doi.org/10.1016/j.quascirev.2011.06.009

Domínguez-Rodrigo, M., Barba, R., 2006. New estimates of tooth mark and percussion mark frequencies at the FLK Zinj site: the carnivore-hominid-carnivore hypothesis falsified. J. Hum. Evol. 50, 170-194. https://doi.org/10.1016/j.jhevol.2005.09.005

Domínguez-Rodrigo, M., Barba, R., Egeland, C.P., 2007. Deconstructing Olduvai: a taphonomic study of the Bed I sites. Springer Science \& Business Media.

Domínguez-Rodrigo, M., Mabulla, A., Bunn, H.T., Barba, R., Diez-Martín, F., Egeland, C.P., Espílez, E., Egeland, A., Yravedra, J., Sánchez, P., 2009. Unraveling hominin behavior at another anthropogenic site from Olduvai Gorge (Tanzania): new archaeological and taphonomic research at BK, Upper Bed II. J. Hum. Evol. 57, 260-283. https://doi.org/10.1016/j.jhevol.2009.04.006

Domínguez-Rodrigo, M., Pickering, T.R., 2003. Early hominid hunting and scavenging: A zooarcheological review. Evol. Anthropol. Issues News Rev. 12, 275-282. https://doi.org/10.1002/evan.10119

Domínguez-Rodrigo, M., 1997. Meat-eating by early hominids at the FLK 22Zinjanthropussite, Olduvai Gorge (Tanzania): an experimental approach using cut-mark data. J. Hum. Evol. 33, 669-690. https://doi.org/10.1006/jhev.1997.0161

Ecker, M., Bocherens, H., Julien, M.-A., Rivals, F., Raynal, J.-P., Moncel, M.-H., 2013. Middle Pleistocene ecology and Neanderthal subsistence: Insights from stable isotope analyses in Payre (Ardèche, southeastern France). J. Hum. Evol. 65, 363-373. https://doi.org/10.1016/j.jhevol.2013.06.013 
Eixea, A., 2018. Middle palaeolithic lithic assemblages in western Mediterranean Europe from MIS 5 to 3. J. Archaeol. Sci. Rep. 21, 643-666. https://doi.org/10.1016/j.jasrep.2018.08.039

Faith, J.T., Du, A., 2018. The measurement of taxonomic evenness in zooarchaeology. Archaeol. Anthropol. Sci. 10, 1419-1428. https://doi.org/10.1007/s12520-017-0467-8

Faith, J.T., Gordon, A.D., 2007a. Skeletal element abundances in archaeofaunal assemblages: economic utility, sample size, and assessment of carcass transport strategies. J. Archaeol. Sci. 34, 872-882. https://doi.org/10.1016/j.jas.2006.08.007

Faith, J.T., Gordon, A.D., 2007b. Skeletal element abundances in archaeofaunal assemblages: economic utility, sample size, and assessment of carcass transport strategies. J. Archaeol. Sci. 34, 872-882. https://doi.org/10.1016/j.jas.2006.08.007

Farizy, C., 1994. Spatial Patterning of Middle Paleolithic Sites. J. Anthropol. Archaeol. 13, 153160. https://doi.org/10.1006/jaar.1994.1010

Farizy, C., David, F., Jaubert, J., 1994. Hommes et bisons du paléolithique moyen à Mauran (Haute-Garonne): XXX supplément à Gallia préhistoire. CNRS éditions, Paris.

Fernandez, P., Legendre, S., 2003. Mortality curves for horses from the Middle Palaeolithic site of Bau de l'Aubesier (Vaucluse, France): methodological, palaeo-ethnological, and palaeoecological approaches. J. Archaeol. Sci. 30, 1577-1598. https://doi.org/10.1016/S03054403(03)00054-2

Fernández-Peris, J., Barciela González, V., Blasco, R., Cuartero, F., Sañudo, P., 2008. El Paleolítico Medio en el territorio valenciano y la variabilidad tecno-económica de la Cova del Bolomor. Treb. Arqueol. 14, 141-169.

Fisher, J.W., 1995. Bone surface modifications in zooarchaeology. J. Archaeol. Method Theory 2, 7-68. https://doi.org/10.1007/BF02228434

Frison, G., 1974. Archeology of the Casper site, in: Casper Site: A Hell Gap Bison Kill on the High Plains. Academic Press, New York, pp. 1-111.

Frison, G.C., 1984. The Carter/Kerr-McGee Paleoindian Site: Cultural Resource Management and Archaeological Research. Am. Antiq. 49, 288-314. https://doi.org/10.2307/280020

Gabucio, M.J., Cáceres, I., Rodríguez-Hidalgo, A., Rosell, J., Saladié, P., 2014a. A wildcat (Felis silvestris) butchered by Neanderthals in Level O of the Abric Romaní site (Capellades, Barcelona, Spain). Quat. Int. 326-327, 307-318. https://doi.org/10.1016/j.quaint.2013.10.051

Gabucio, M.J., Cáceres, I., Rosell, J., Saladié, P., Vallverdú, J., 2014b. From small bone fragments to Neanderthal activity areas: The case of Level O of the Abric Romaní (Capellades, Barcelona, Spain). Quat. Int. 330, 36-51. https://doi.org/10.1016/j.quaint.2013.12.015

Gamble, C., Boismier, W.A., 1991. Ethnoarchaeological approaches to mobile campsites: hunter gatherer and pastoralist case studies. International Monographs in Prehistory, Ann Arbor.

Gaudzinski, S., 2006. Monospecific or Species-Dominated Faunal Assemblages During the Middle Paleolithic in Europe, in: Hovers, E., Kuhn, S.L. (Eds.), Transitions Before the Transition: Evolution and Stability in the Middle Paleolithic and Middle Stone Age. Springer US, Boston, MA, pp. 137-147. https://doi.org/10.1007/0-387-24661-4_8

Gaudzinski, S., Roebroeks, W., 2000. Adults only. Reindeer hunting at the Middle Palaeolithic site Salzgitter Lebenstedt, Northern Germany. J. Hum. Evol. 38, 497-521.

https://doi.org/10.1006/jhev.1999.0359

Gaudzinski-Windheuser, S., Noack, E.S., Pop, E., Herbst, C., Pfleging, J., Buchli, J., Jacob, A., Enzmann, F., Kindler, L., Iovita, R., Street, M., Roebroeks, W., 2018. Evidence for closerange hunting by last interglacial Neanderthals. Nat. Ecol. Evol. 2, 1087-1092. https://doi.org/10.1038/s41559-018-0596-1

Grayson, D.K., 1984. Quantitative zooarchaeology: topics in the quantification of archaeofaunas. Orlando Acad. 
Hardy, B.L., Moncel, M.-H., 2011. Neanderthal Use of Fish, Mammals, Birds, Starchy Plants and Wood 125-250,000 Years Ago. PLOS ONE 6, e23768.

https://doi.org/10.1371/journal.pone.0023768

Hardy, B.L., Moncel, M.-H., Daujeard, C., Fernandes, P., Béarez, P., Desclaux, E., Chacon Navarro, M.G., Puaud, S., Gallotti, R., 2013. Impossible Neanderthals? Making string, throwing projectiles and catching small game during Marine Isotope Stage 4 (Abri du Maras, France). Quat. Sci. Rev. 82, 23-40. https://doi.org/10.1016/j.quascirev.2013.09.028

Hardy, B.L., Moncel, M.-H., Kerfant, C., Lebon, M., Bellot-Gurlet, L., Mélard, N., 2020. Direct evidence of Neanderthal fibre technology and its cognitive and behavioral implications. Sci. Rep. 10, 4889. https://doi.org/10.1038/s41598-020-61839-w

Hayden, B., 1981. Subsistence and ecological adaptations of modern hunter/gatherers.

Hitchcock, R.K., Crowell, A.L., Brooks, A.S., Yellen, J.E., Ebert, J.I., Osborn, A.J., 2019. The Ethnoarchaeology of Ambush Hunting: A Case Study of $¥$ Gi Pan, Western Ngamiland, Botswana. Afr. Archaeol. Rev. 36, 119-144. https://doi.org/10.1007/s10437-018-9319-x

Isaac, G., 1978. The Food-sharing Behavior of Protohuman Hominids. Sci. Am. 238, 90-109.

Isaac, G.L., 1983. Bones in contention: competing explanations for the juxtaposition of Early Pleistocene artifacts and faunal remains. Anim. Archaeol. 1, 3-19.

Jaouen, K., Richards, M.P., Le Cabec, A., Welker, F., Rendu, W., Hublin, J.-J., Soressi, M., Talamo, S., 2019. Exceptionally high $\delta^{15} \mathrm{~N}$ values in collagen single amino acids confirm Neandertals as high-trophic level carnivores. Proc. Natl. Acad. Sci. 116, 4928. https://doi.org/10.1073/pnas.1814087116

Jaubert, J., Brugal, J.P., 1990. Contribution à l'étude du mode de vie au Paléolithique moyen: Les chasseurs d'aurochs de La Borde, in: Les Chasseurs d'aurochs de La Borde: Un Site Du Paléolithique Moyen (Livernon, Lot). Maison des Sciences de l'Homme, Paris, pp. 128145.

Jones, K.T., 1983. Forager archaeology: the Ache of eastern Paraguay, in: Carnivores, Human Scavengers \& Predators: A Question of Bone Technology. Presented at the proceedings of the Fifteenth Annual Conference, the Archaeological Association of the University of Calgary, University of Calgary, Calgary, pp. 171-192.

Kelly, R.L., 2013. The Lifeways of Hunter-Gatherers: The Foraging Spectrum. Cambridge University Press.

Kent, S., 1987. Understanding the Use of Space: An Ethnoarchaeological Approach, in: Method and Theory for Activity Area Research. An Ethnoarchaeological Approach. Columbia University Press, New York, pp. 1-60.

Klein, R.G., Cruz-Uribe, K., 1983. The computation of ungulate age (mortality) profiles from dental crown heights. Paleobiology 9, 70-78. https://doi.org/10.1017/S0094837300007399

Kroll, E.M., Price, T.D., 1991. The Interpretation of Archaeological Spatial Patterning. Plenum Press, New York.

Kuhn, S.L., 2013. Cultural Transmission, Institutional Continuity and the Persistence of the Mousterian, in: Akazawa, T., Nishiaki, Y., Aoki, K. (Eds.), Dynamics of Learning in Neanderthals and Modern Humans Volume 1: Cultural Perspectives. Springer Japan, Tokyo, pp. 105-113. https://doi.org/10.1007/978-4-431-54511-8_6

Kuhn, S.L., 1992. On Planning and Curated Technologies in the Middle Paleolithic. J. Anthropol. Res. 48, 185-214. https://doi.org/10.1086/jar.48.3.3630634

Lam, Y.M., Chen, X., Pearson, O.M., 1999. Intertaxonomic Variability in Patterns of Bone Density and the Differential Representation of Bovid, Cervid, and Equid Elements in the Archaeological Record. Am. Antiq. 64, 343-362. https://doi.org/10.2307/2694283

Lee, R., 2012. The Dobe Ju/'hoansi. Nelson Education.

Levine, M.A., 1998. Eating horses: the evolutionary significance of hippophagy. Antiquity 72, 90100. https://doi.org/10.1017/S0003598X00086300 
Levine, M.A., 1983. Mortality models and the interpretation of horse population structure. Cambridge University Press, Cambridge, UK.

Levine, M.A., 1982. The use of crown height measurements and eruption-wear sequences to age horse teeth, in: Ageing and Sexing Animal Bones from Archaeological Sites. Oxford, pp. $223-250$.

Lupo, K.D., 2006. What Explains the Carcass Field Processing and Transport Decisions of Contemporary Hunter-Gatherers? Measures of Economic Anatomy and Zooarchaeological Skeletal Part Representation. J. Archaeol. Method Theory 13, 19-66. https://doi.org/10.1007/s10816-006-9000-6

Lupo, K.D., 2001. Archaeological Skeletal Part Profiles and Differential Transport: An Ethnoarchaeological Example from Hadza Bone Assemblages. J. Anthropol. Archaeol. 20, 361-378. https://doi.org/10.1006/jaar.2000.0378

Lupo, K.D., 1998. Experimentally Derived Extraction Rates for Marrow: Implications for Body Part Exploitation Strategies of Plio-Pleistocene Hominid Scavengers. J. Archaeol. Sci. 25, 657-675. https://doi.org/10.1006/jasc.1997.0261

Lupo, K.D., O’Connell, J.F., 2002. Cut and Tooth Mark Distributions on Large Animal Bones: Ethnoarchaeological Data from the Hadza and Their Implications For Current Ideas About Early Human Carnivory. J. Archaeol. Sci. 29, 85-109. https://doi.org/10.1006/jasc.2001.0690

Lyman, R.L., 1994. Vertebrate Taphonomy. Cambridge University Press.

Mallye, J.-B., Thiébaut, C., Mourre, V., Costamagno, S., Claud, É., Weisbecker, P., 2012. The Mousterian bone retouchers of Noisetier Cave: experimentation and identification of marks. J. Archaeol. Sci. 39, 1131-1142. https://doi.org/10.1016/j.jas.2011.12.018

Marean, C.W., 2005. From the tropics to the colder climates: contrasting faunal exploitation adaptations of modern humans and Neanderthals. Tools Symb. Early Hominids Mod. Hum. 333-371.

Marean, C.W., Assefa, Z., 1999. Zooarcheological evidence for the faunal exploitation behavior of Neandertals and early modern humans. Evol. Anthropol. Issues News Rev. 8, 22-37. https://doi.org/10.1002/(SICI)1520-6505(1999)8:1<22::AID-EVAN7>3.0.CO;2-F

Marean, C.W., Cleghorn, N., 2003. Large mammal skeletal element transport: applying foraging theory in a complex taphonomic system. J. Taphon. 1, 15-42.

Mariezkurrena, K., 1983. Contribucioón al conocimiento del desarollo de la denticioón y el esqueleto poscraneal de Cervus elaphus. Munibe Soc. Cienc. Aranzadi 35, 149-202.

Marín, J., Rodríguez-Hidalgo, A., Vallverdú, J., Gómez de Soler, B., Rivals, F., Rabuñal, J.R., Pineda, A., Chacón, M.G., Carbonell, E., Saladié, P., 2019. Neanderthal logistic mobility during MIS3: Zooarchaeological perspective of Abric Romaní level P (Spain). Quat. Sci. Rev. 225, 106033. https://doi.org/10.1016/j.quascirev.2019.106033

Marín, J., Saladié, P., Rodríguez-Hidalgo, A., Carbonell, E., 2017a. Neanderthal hunting strategies inferred from mortality profiles within the Abric Romaní sequence. PLOS ONE 12, e0186970. https://doi.org/10.1371/journal.pone.0186970

Marín, J., Saladié, P., Rodríguez-Hidalgo, A., Carbonell, E., 2017b. Ungulate carcass transport strategies at the Middle Palaeolithic site of Abric Romaní (Capellades, Spain). Comptes Rendus Palevol 16, 103-121. https://doi.org/10.1016/j.crpv.2015.11.006

Marín-Arroyo, A.B., 2013. Palaeolithic Human Subsistence in Mount Carmel (Israel). A Taphonomic Assessment of Middle and Early Upper Palaeolithic Faunal Remains from Tabun, Skhul and el-Wad. Int. J. Osteoarchaeol. 23, 254-273. https://doi.org/10.1002/oa.1241

Martínez-Moreno, J., Mora, R., de La Torre, I., 2004. Methodological approach for understanding middle palaeolithic settlement dynamics at La Roca dels Bous (Noguera, Catalunya, 
Northeast Spain)., in: Settlement Dynamics of the Middle Paleolithic and Middle Stone Age. Kerns Verlag, Tübingen, pp. 393-413.

Miller, C., 1974. Dentition as an indicator of age and sex; composition and socialization of the population. Spalding Printing Company Limited.

Miller, F.L., 1974. Biology of the Kaminuriak population of barren-ground caribou, Part 2:

Dentition as an indicator of age and sex; composition and socialization of the population.

Canadian Wildlife Service.

Monahan, C.M., 1998. The Hadza Carcass Transport Debate Revisited and its Archaeological Implications. J. Archaeol. Sci. 25, 405-424. https://doi.org/10.1006/jasc.1997.0241

Moncel, M., Daujeard, C., 2012. The variability of the Middle Palaeolithic on the right bank of the Middle Rhône Valley (southeast France): Technical traditions or functional choices? Quat. Int. 247, 103-124. https://doi.org/10.1016/j.quaint.2010.10.030

Moncel, M.-H., 2010. L'abri Des Pêcheurs (Ardèche, Sud-Est France). Des Occupations Néandertaliennes Dans Une «grotte En Forme de Fissure». Ann D’Universite Valahia Targoviste Sect D'Archeologie D'Histoire 12, 7-21.

Moncel, M.-H., 1994. L'industrie lithique des trois niveaux supérieurs de l'Abri du Maras (Ardèche). Ind. Laminaires Au Paléolithique Moyen Doss. Doc. Archéologique 18, 118 123.

Moncel, M.-H., Chacón, M.G., La Porta, A., Fernandes, P., Hardy, B., Gallotti, R., 2014. Fragmented reduction processes: Middle Palaeolithic technical behaviour in the Abri du Maras shelter, southeastern France. Quat. Int. 350, 180-204. https://doi.org/10.1016/j.quaint.2014.05.013

Moncel, M.-H., Daujeard, C., Crégut-Bonnoure, E., Boulbes, N., Puaud, S., Debard, E., Bailon, S., Desclaux, E., Escude, É., Roger, T., Dubar, M., 2010. Nouvelles données sur les occupations humaines du début du Pléistocène supérieur de la moyenne vallée du Rhône (France). Les sites de l'abri des pêcheurs, de la Baume Flandin, de l'Abri du Maras et de la grotte du Figuier (Ardèche). Quat. Rev. Assoc. Fr. Pour Létude Quat. 385-411. https://doi.org/10.4000/quaternaire.9212

Moncel, M.-H., Daujeard, C., Crégut-Bonnoure, E., Fernandez, P., Faure, M., Guérin, C., 2004. L'occupation de la grotte de Saint-Marcel (Ardèche, France) au Paléolithique moyen : stratégie d'exploitation de l'environnement et type d'occupation de la grotte. L'exemple des couches i, j et j'. Bull. Société Préhistorique Fr. 257-304.

Moncel, M.-H., Daujeard, C., Navarro, M.G.C., Vettese, D., Fernandes, P., Hardy, B., Puaud, S., Richard, M., Allué, E., Bearez, P., Boulbes, N., Britton, K., Courty, M.-A., CrégutBonnoure, E., Desclaux, E., Gallotti, R., Joannes-Boyau, R.R., Kerfant, C., Lateur, N., Porta, A.L., Limondin-Lozouet, N., Marin, J., Rivals, F.P.-T.A., Bahain, J.-J.R.T., Falguères, C., 2018. Abri du Maras (Saint-Martin d'Ardèche). Un habitat néandertalien occupé il y a 90000 et 40000 ans. Ardèche Archéologie VansFédération Ardéchoise Rech. Préhistorique 35.

Moncel, M.-H., Fernandes, P., Willmes, M., James, H., Grün, R., 2019. Rocks, teeth, and tools: New insights into early Neanderthal mobility strategies in South-Eastern France from lithic reconstructions and strontium isotope analysis. PLOS ONE 14, e0214925. https://doi.org/10.1371/journal.pone.0214925

Moncel, M.-H., Gaillard, C., Patou-Mathis, M., 1994. L'abri du Maras (Ardèche) : une nouvelle campagne de fouilles dans un site Paléolithique moyen (1993). Bull. Société Préhistorique Fr. 363-368.

Moncel, M.-H., Michel, V., 2000. Première datation radiométrique par U-Th d'un niveau moustérien de l'Abri du Maras (Ardèche, France). Bull. Société Préhistorique Fr. 97, 371375 . 
Morin, E., 2007. Fat composition and Nunamiut decision-making: a new look at the marrow and bone grease indices. J. Archaeol. Sci. 34, 69-82. https://doi.org/10.1016/j.jas.2006.03.015

Morin, E., Ready, E., 2013. Foraging Goals and Transport Decisions in Western Europe during the Paleolithic and Early Holocene, in: Clark, J.L., Speth, J.D. (Eds.), Zooarchaeology and Modern Human Origins: Human Hunting Behavior during the Later Pleistocene. Springer Netherlands, Dordrecht, pp. 227-269. https://doi.org/10.1007/978-94-007-6766-9_14

Murray, N.A., 1993. The behavioural ecology of reindeer (Rangifer tarandus) during the last glaciation in Britain and its implications for human settlement, subsistence and mobility. University of Edimburg, Scotland.

Naito, Y.I., Chikaraishi, Y., Drucker, D.G., Ohkouchi, N., Semal, P., Wißing, C., Bocherens, H., 2016. Ecological niche of Neanderthals from Spy Cave revealed by nitrogen isotopes of individual amino acids in collagen. J. Hum. Evol. 93, 82-90.

https://doi.org/10.1016/j.jhevol.2016.01.009

Nilssen, P.J., 2000. An actualistic butchery study in South Africa and its implications for reconstructing hominid strategies of carcass acquisition and butchery in the Upper Pleistocene and Plio-Pleistocene. University of Cape Town South Africa.

Niven, L., 2013. A Diachronic Evaluation of Neanderthal Cervid Exploitation and Site Use at Pech de l'Azé IV, France, in: Clark, J.L., Speth, J.D. (Eds.), Zooarchaeology and Modern Human Origins: Human Hunting Behavior during the Later Pleistocene. Springer Netherlands, Dordrecht, pp. 151-161. https://doi.org/10.1007/978-94-007-6766-9_9

Niven, L., 2007. From carcass to cave: Large mammal exploitation during the Aurignacian at Vogelherd, Germany. J. Hum. Evol. 53, 362-382. https://doi.org/10.1016/j.jhevol.2007.05.006

Niven, L., Steele, T.E., Rendu, W., Mallye, J.-B., McPherron, S.P., Soressi, M., Jaubert, J., Hublin, J.-J., 2012. Neandertal mobility and large-game hunting: The exploitation of reindeer during the Quina Mousterian at Chez-Pinaud Jonzac (Charente-Maritime, France). J. Hum. Evol. 63, 624-635. https://doi.org/10.1016/j.jhevol.2012.07.002

Oakley, K.P., Andrews, P., Keeley, L.H., Clark, J.D., 1977. A Reappraisal of the Clacton Spearpoint. Proc. Prehist. Soc. 43, 13-30. https://doi.org/10.1017/S0079497X00010343

O’Connell, J.F., Hawkes, K., Blurton-Jones, N.G., 1992. Patterns in the distribution, site structure and assemblage composition of Hadza kill-butchering sites. J. Archaeol. Sci. 19, 319-345. https://doi.org/10.1016/0305-4403(92)90020-4

O’Connell, J.F., Hawkes, K., Jones, N.B., 1988. Hadza Hunting, Butchering, and Bone Transport and Their Archaeological Implications. J. Anthropol. Res. 44, 113-161. https://doi.org/10.1086/jar.44.2.3630053

Patou-Mathis, M., 2012. Interactions between Neanderthals and carnivores in Eastern Europe. J. Taphon. 10, 277-290.

Patou-Mathis, M., 2000. Neanderthal subsistence behaviours in Europe. Int. J. Osteoarchaeol. 10, 379-395. https://doi.org/10.1002/1099-1212(200009/10)10:5<379::AID-OA558>3.0.CO;24

Patou-Mathis, M., 1994. Archéozoologie des niveaux moustériens et aurignaciens de la grotte Tournal à Bize (aude). Gall. Préhistoire 36, 1-64. https://doi.org/10.3406/galip.1994.2092

Potts, R., Shipman, P., 1981. Cutmarks made by stone tools on bones from Olduvai Gorge, Tanzania. Nature 291, 577-580. https://doi.org/10.1038/291577a0

Puaud, S., Nowak, M., Pont, S., Moncel, M.-H., 2015. Minéraux volcaniques et alpins à l'abri du Maras (Ardèche, France) : témoins de vents catabatiques dans la vallée du Rhône au Pléistocène supérieur. Comptes Rendus Palevol 14, 331-341. https://doi.org/10.1016/j.crpv.2015.02.007

Real, C., Eixea, A., Sanchis, A., Morales, J.V., Klasen, N., Zilhão, J., Villaverde, V., 2018. Abrigo de la Quebrada Level IV (Valencia, Spain): Interpreting a Middle Palaeolithic Palimpsest 
from a Zooarchaeological and Lithic Perspective. J. Paleolit. Archaeol.

https://doi.org/10.1007/s41982-018-0012-z

Real, C., Sanchis, A., Eixea, A., Villaverde, V., 2019. Neanderthal subsistence and short-term human occupation patterns during MIS 5. New data from Abrigo de la Quebrada (Valencia, Spain). J. Archaeol. Sci. Rep. 28, 102056. https://doi.org/10.1016/j.jasrep.2019.102056

Reynard, J.P., Henshilwood, C.S., 2017. Subsistence strategies during the Late Pleistocene in the southern Cape of South Africa: Comparing the Still Bay of Blombos Cave with the Howiesons Poort of Klipdrift Shelter. J. Hum. Evol. 108, 110-130. https://doi.org/10.1016/j.jhevol.2017.04.003

Richard, M., Falguères, C., Pons-Branchu, E., Bahain, J.-J., Voinchet, P., Lebon, M., Valladas, H., Dolo, J.-M., Puaud, S., Rué, M., Daujeard, C., Moncel, M.-H., Raynal, J.-P., 2015. Contribution of ESR/U-series dating to the chronology of late Middle Palaeolithic sites in the middle Rhône valley, southeastern France. LED14 Proc. 30, 529-534. https://doi.org/10.1016/j.quageo.2015.06.002

Richards, M.P., 2009. Stable Isotope Evidence for European Upper Paleolithic Human Diets, in: Hublin, J.-J., Richards, M.P. (Eds.), The Evolution of Hominin Diets: Integrating Approaches to the Study of Palaeolithic Subsistence. Springer Netherlands, Dordrecht, pp. 251-257. https://doi.org/10.1007/978-1-4020-9699-0_20

Richards, M.P., Trinkaus, E., 2009. Isotopic evidence for the diets of European Neanderthals and early modern humans. Proc. Natl. Acad. Sci. 106, 16034. https://doi.org/10.1073/pnas.0903821106

Rivals, F., Prignano, L., Semprebon, G.M., Lozano, S., 2015. A tool for determining duration of mortality events in archaeological assemblages using extant ungulate microwear. Sci. Rep. 5,17330 .

Rivals, F., Semprebon, G.M., 2017. Latitude matters: an examination of behavioural plasticity in dietary traits amongst extant and Pleistocene Rangifer tarandus. Boreas 46, 254-263. https://doi.org/10.1111/bor.12205

Rodríguez-Hidalgo, A., Saladié, P., Ollé, A., Carbonell, E., 2015. Hominin subsistence and site function of TD10.1 bone bed level at Gran Dolina site (Atapuerca) during the late Acheulean. J. Quat. Sci. 30, 679-701. https://doi.org/10.1002/jqs.2815

Rosell, J., Cáceres, I., Blasco, R., Bennàsar, M., Bravo, P., Campeny, G., Esteban-Nadal, M., Fernández-Laso, M.C., Gabucio, M.J., Huguet, R., Ibáñez, N., Martín, P., Rivals, F., Rodríguez-Hidalgo, A., Saladié, P., 2012. A zooarchaeological contribution to establish occupational patterns at Level J of Abric Romaní (Barcelona, Spain). Quat. Int. 247, 69-84. https://doi.org/10.1016/j.quaint.2011.01.020

Rufà, A., Blasco, R., Rivals, F., Rosell, J., 2016. Who eats whom? Taphonomic analysis of the avian record from the Middle Paleolithic site of Teixoneres Cave (Moià, Barcelona, Spain). Quat. Int. 421, 103-115. https://doi.org/10.1016/j.quaint.2015.06.055

Rufà, A., Blasco, R., Rivals, F., Rosell, J., 2014. Leporids as a potential resource for predators (hominins, mammalian carnivores, raptors): An example of mixed contribution from level III of Teixoneres Cave (MIS 3, Barcelona, Spain). Comptes Rendus Palevol 13, 665-680. https://doi.org/10.1016/j.crpv.2014.06.001

Saladié, P., Huguet, R., Díez, C., Rodríguez-Hidalgo, A., Cáceres, I., Vallverdú, J., Rosell, J., Bermúdez de Castro, J.M., Carbonell, E., 2011. Carcass transport decisions in Homo antecessor subsistence strategies. J. Hum. Evol. 61, 425-446. https://doi.org/10.1016/j.jhevol.2011.05.012

Schoch, W.H., Bigga, G., Böhner, U., Richter, P., Terberger, T., 2015. New insights on the wooden weapons from the Paleolithic site of Schöningen. Spec. Issue Excav. Schöning. New Insights Middle Pleistocene Lifeways North. Eur. 89, 214-225. https://doi.org/10.1016/j.jhevol.2015.08.004 
Schoville, B.J., Otárola-Castillo, E., 2014. A model of hunter-gatherer skeletal element transport: The effect of prey body size, carriers, and distance. J. Hum. Evol. 73, 1-14. https://doi.org/10.1016/j.jhevol.2014.06.004

Selvaggio, M.M., 1998. Evidence for a Three-Stage Sequence of Hominid and Carnivore Involvement with Long Bones at FLKZinjanthropus, Olduvai Gorge, Tanzania. J. Archaeol. Sci. 25, 191-202. https://doi.org/10.1006/jasc.1997.0281

Selvaggio, M.M., Wilder, J., 2001. Identifying the Involvement of Multiple Carnivore Taxa with Archaeological Bone Assemblages. J. Archaeol. Sci. 28, 465-470. https://doi.org/10.1006/jasc.2000.0557

Shipman, P., 1981. Life History of a Fossil: An Introduction to Taphonomy and Paleoecology. Harvard University Press, Cambridge.

Shipman, P., Rose, J., 1983. Early hominid hunting, butchering, and carcass-processing behaviors: Approaches to the fossil record. J. Anthropol. Archaeol. 2, 57-98. https://doi.org/10.1016/0278-4165(83)90008-9

Smith, G.M., 2015. Neanderthal megafaunal exploitation in Western Europe and its dietary implications: A contextual reassessment of La Cotte de St Brelade (Jersey). J. Hum. Evol. 78, 181-201. https://doi.org/10.1016/j.jhevol.2014.10.007

Solounias, N., Semprebon, G., 2002. Advances in the Reconstruction of Ungulate Ecomorphology with Application to Early Fossil Equids. Am. Mus. Novit. 2002, 1-49. https://doi.org/10.1206/0003-0082(2002)366<0001:AITROU>2.0.CO;2

Speth, J., 2012. Middle Palaeolithic subsistence in the Near East: zooarchaeological perspectivespast, present and future. Farming 2012, 1-45.

Speth, J.D., 2019. Neanderthals, vitamin C, and scurvy. Quat. Int. 500, 172-184. https://doi.org/10.1016/j.quaint.2018.11.042

Steele, T.E., Weaver, T.D., 2002. The Modified Triangular Graph: A Refined Method for Comparing Mortality Profiles in Archaeological Samples. J. Archaeol. Sci. 29, 317-322. https://doi.org/10.1006/jasc.2001.0733

Stiner, M.C., 2013. An Unshakable Middle Paleolithic? Trends versus Conservatism in the Predatory Niche and Their Social Ramifications. Curr. Anthropol. 54, S288-S304. https://doi.org/10.1086/673285

Stiner, M.C., 1994. Honor among thieves: A zooarchaeological study of Neandertal ecology. Princeton University Press, Princeton.

Stiner, M.C., 1991. The Faunal Remains From Grotta Guattari: A Taphonomic Perspective. Curr. Anthropol. 32, 103-117. https://doi.org/10.1086/203930

Stiner, M.C., 1990. The use of mortality patterns in archaeological studies of hominid predatory adaptations. J. Anthropol. Archaeol. 9, 305-351. https://doi.org/10.1016/02784165(90)90010-B

Stiner, M.C., Barkai, R., Gopher, A., 2009. Cooperative hunting and meat sharing 400-200 kya at Qesem Cave, Israel. Proc. Natl. Acad. Sci. 106, 13207-13212. https://doi.org/10.1073/pnas.0900564106

Stiner, M.C., Kuhn, S.L., 2006. Changes in the 'Connectedness' and Resilience of Paleolithic Societies in Mediterranean Ecosystems. Hum. Ecol. 34, 693-712. https://doi.org/10.1007/s10745-006-9041-1

Thieme, H., 1997. Lower Palaeolithic hunting spears from Germany. Nature 385, 807-810. https://doi.org/10.1038/385807a0

Turq, A., Faivre, J.-P., Gravina, B., Bourguignon, L., 2017. Building models of Neanderthal territories from raw material transports in the Aquitaine Basin (southwestern France). Clean. Messy Mousterian Descr. Interpret Late Middle Palaeolithic Chrono-Cult. Var. Atl. Eur. 433, 88-101. https://doi.org/10.1016/j.quaint.2016.02.062 
Vallverdú, J., Allué, E., Bischoff, J.L., Cáceres, I., Carbonell, E., Cebrià, A., García-Antón, D., Huguet, R., Ibáñez, N., Martínez, K., Pastó, I., Rosell, J., Saladié, P., Vaquero, M., 2005. Short human occupations in the Middle Palaeolithic level i of the Abric Romaní rock-shelter (Capellades, Barcelona, Spain). J. Hum. Evol. 48, 157-174. https://doi.org/10.1016/j.jhevol.2004.10.004

Vaquero, M., 2008. The history of stones: behavioural inferences and temporal resolution of an archaeological assemblage from the Middle Palaeolithic. J. Archaeol. Sci. 35, 3178-3185. https://doi.org/10.1016/j.jas.2008.07.006

Vaquero, M., Romagnoli, F., 2018. Searching for Lazy People: the Significance of Expedient Behavior in the Interpretation of Paleolithic Assemblages. J. Archaeol. Method Theory 25, 334-367. https://doi.org/10.1007/s 10816-017-9339-x

Vettese, D., Blasco, R., Cáceres, I., Gaudzinski-Windheuser, S., Moncel, M.-H., Hohenstein, U.T., Daujeard, C., 2020. Towards an understanding of hominin marrow extraction strategies: a proposal for a percussion mark terminology. Archaeol. Anthropol. Sci. 12, 48. https://doi.org/10.1007/s12520-019-00972-8

Vettese, D., Daujeard, C., Blasco, R., Borel, A., Caceres, I., Moncel, M.H., 2017. Neandertal long bone breakage process: Standardized or random patterns? The example of Abri du Maras (Southeastern France, MIS 3). J. Archaeol. Sci. Rep. 13, 151-163. https://doi.org/10.1016/j.jasrep.2017.03.029

Villa, P., Lenoir, M., 2009. Hunting and Hunting Weapons of the Lower and Middle Paleolithic of Europe, in: Hublin, J.-J., Richards, M.P. (Eds.), The Evolution of Hominin Diets: Integrating Approaches to the Study of Palaeolithic Subsistence. Springer Netherlands, Dordrecht, pp. 59-85. https://doi.org/10.1007/978-1-4020-9699-0_5

Villa, P., Mahieu, E., 1991. Breakage patterns of human long bones. J. Hum. Evol. 21, 27-48. https://doi.org/10.1016/0047-2484(91)90034-S

Villaverde, V., Eixea, A., Zilhão, J., Sanchis, A., Real, C., Bergadà, M., 2017. Diachronic variation in the Middle Paleolithic settlement of Abrigo de la Quebrada (Chelva, Spain). Quat. Int. 435, 164-179. https://doi.org/10.1016/j.quaint.2015.09.075

Wißing, C., Rougier, H., Crevecoeur, I., Germonpré, M., Naito, Y.I., Semal, P., Bocherens, H., 2016. Isotopic evidence for dietary ecology of late Neandertals in North-Western Europe. Middle Palaeolithic North-West Eur. Multidiscip. Approaches 411, 327-345. https://doi.org/10.1016/j.quaint.2015.09.091

Yellen, J.E., 1977. Cultural patterning in faunal remains: evidence from the !Kung bushmen, in: Experimental Archeology. Columbia University Press, New York, pp. 271-331.

Yeshurun, R., Bar-Oz, G., Weinstein-Evron, M., 2007. Modern hunting behavior in the early Middle Paleolithic: Faunal remains from Misliya Cave, Mount Carmel, Israel. J. Hum. Evol. 53, 656-677. https://doi.org/10.1016/j.jhevol.2007.05.008

Yravedra, J., Cobo-Sánchez, L., 2015. Neanderthal exploitation of ibex and chamois in southwestern Europe. J. Hum. Evol. 78, 12-32. https://doi.org/10.1016/j.jhevol.2014.10.002

Yravedra, J., Domínguez-Rodrigo, M., 2009. The shaft-based methodological approach to the quantification of long limb bones and its relevance to understanding hominid subsistence in the Pleistocene: application to four Palaeolithic sites. J. Quat. Sci. 24, 85-96. https://doi.org/10.1002/jqs.1164 